\title{
An Empirical Analysis of the Effects of the Threat of Takeover on UK Company Performance
}

\author{
Robin Nuttall ${ }^{1}$ \\ Nuffield College, \\ Oxford, \\ OX1 1NF, UK.
}

3 February 1999

${ }^{1}$ This paper is based on Essay 4 of my doctoral thesis at Oxford University. I thank Steve Bond for his extensive advice and encouragement. I am also grateful to Scott Evans, Colin Mayer, Daphne Nicolitsas, Jon Temple and Frank Windmeijer, plus seminar participants at Oxford and the London Business School. Any errors are mine. 


\begin{abstract}
This paper undertakes an empirical analysis of the effects of the threat of takeover on company performance, based on a panel of 643 nonfinancial quoted UK companies over the period 1989-96. Our measure of the intensity of the threat of takeover is the predicted probability of takeover estimated recursively from a takeover likelihood model. This measure is used as an explanatory variable in models of total factor productivity, investment and dividends. We find that takeover risk has a positive and significant effect on subsequent productivity, a negative and significant effect on investment, and a positive but insignificant effect on current dividend payout. The probability of hostile takeover has little effect on productivity, but has a negative and significant effect on investment with a lag of two years, and a strongly positive effect on dividend payout. The probability of friendly takeover has similar effects to the aggregate takeover risk. These results are partially consistent with both a disciplinary view of takeovers and with a short-termism view.
\end{abstract}

JEL classification: G34, L21.

Keywords: Takeover threat; productivity; investment; dividends. 


\section{Introduction}

"A large theoretical and anecdotal literature argues that the American corporate governance system, particularly takeovers, imposes short horizons on the behavior of corporate managers, and hence reduces the efficiency of investment. The theories and the arguments in this area are still remarkably short of any empirical support." (Shleifer and Vishny, 1997, p.772).

Since the work of Marris (1963), Manne (1965), and Morck, Shleifer and Vishny (1988), it has become customary to distinguish two channels through which takeover affects company performance. First, there is an ex post asset matching channel, whereby a consummated takeover enables existing human and physical assets to be recombined in the participating firms. Secondly, there is an ex ante threat effect, whereby the mere existence of the possibility that a company will be acquired alters the way in which the incumbent manager allocates effort between tasks.

A large literature has investigated the ex post effects of takeover and merger. ${ }^{1}$ However, there has been almost no work that attempts to measure directly the effects of the threat of takeover on company performance. ${ }^{2}$ This is surprising, since an understanding of the magnitude of this threat effect is crucial to an assessment of the overall effect of takeover on company performance, and it remains a source of controversy. Marris (1963) was the first to identify the possible role of the takeover threat as a spur to value-enhancement by company managers. More recently, however, some commentators have argued that the threat of takeover leads to short-termism, underinvestment and worsened long-term performance. For example Layard (1997) contends that "hostile takeover does not, on average, improve long-run performance. But the threat of it forces managers to pay undue attention to short-term profit, often at the expense of long-term development" (p.117), so that "takeovers should become more costly" (p.109).

As the quotation from Shleifer and Vishny indicates, this controversy persists in part

\footnotetext{
${ }^{1}$ See Loughran-Vijh (1997), Rau-Vermaelen (1998) and Kaplan-Mitchell-Wruck (1996), plus the surveys by Milgrom-Roberts (1992, Chs. 6 \& 15), Nickell (1995, Chs. 2-3) and Shleifer-Vishny (1997).

${ }^{2}$ See Section 2 below for references.
} 
because of the lack of empirical evidence on the efficacy of the takeover mechanism. This paper attempts to respond to Shleifer and Vishny's observation, by measuring directly the effects of the threat of takeover on company performance. To do so, it employs a simple two-stage methodology. In the first stage, various company- and time-specific measures of the intensity of the threat of takeover are constructed using the predicted probabilities from a takeover likelihood model. In the second stage, these measures are used as regressors in panel data models with measures of company performance as the dependent variable. We use a panel of 643 UK quoted companies over the period 1989-96, containing 108 friendly takeover bids and 49 hostile takeover bids, to examine three dimensions of company performance: total factor productivity, investment and dividends. In order to control for the possible endogeneity of takeover risk, we make use of instrumental variables methods for panel data developed recently by Arellano-Bond (1991), Arellano-Bover (1995) and Blundell-Bond (1998).

The UK stock market seems a good place to study the threat of hostile takeover since, first, hostile takeovers are far more common than in the rest of Europe (Franks and Mayer, 1990) and, secondly, anti-takeover defence mechanisms, such as poison pills, are much less prevalent than in the US (Franks and Mayer, 1996).

The main findings of the paper are discussed in Sections 5, 6 and 7 below, but in brief are as follows. The overall takeover risk-namely aggregating together the probabilities of hostile and friendly takeovers-has a positive and significant lagged effect on productivity, a negative and significant lagged effect on investment, and a positive but insignificant effect on current dividend payout. When we distinguish between the probability of friendly and hostile takeover, we find that the friendly effects mirror the aggregate effects, except for the absence of the positive effect on current dividends. The lagged probability of hostile takeover has an effect on productivity that is statistically indistinguishable both from zero and from the friendly effect (which is positive). The probability of hostile takeover has a significant negative effect on investment with a lag of two accounting years, and a strongly positive effect on current dividend payout. These findings are partially consistent with both a disciplinary view of the threat of 
takeover and with a short-termism view.

The remainder of the paper is organized as follows. Section 2 summarizes existing empirical literature relevant to the study. Section 3 draws out the empirical predictions of existing theory for the effects of the threat of takeover on corporate performance. Section 4 outlines the empirical approach, and presents takeover likelihood models. Section 5 presents the specification of and results from the performance models. Our findings are discussed in Section 6. Section 7 concludes.

\section{Existing literature}

With the exception of Bond-Meghir-Windmeijer (1998), discussed below, we are aware of no work that systematically measures the effects of the threat of takeover on company performance. However, there have been several studies that examine the effect indirectly, and these fall into three categories: studies of pre-bid performance; studies of cross-sectional or time-series variation in takeover regulation; and studies of the effect of external corporate control events on corporate performance.

By assessing whether takeovers actually select underperforming companies, studies of pre-bid performance attempt to cast light on the scope for takeovers to act as a discipline device. For univariate studies of share-price performance preceding a hostile takeover bid, there appears to be evidence in the US that takeover targets under perform (Martin and McConnell, 1991), while the evidence for the UK is less strong (Franks and Mayer, 1996). In the US there is evidence that nonquoted takeover targets as a whole are more profitable than nontargets, but that tender offer targets are less profitable than nontargets (Ravenscraft and Scherer, 1987). The US evidence suggests that nonquoted takeover targets have above average productivity, although buyers are more likely to purchase poorly-performing companies as target size increases (McGuckin-Nguyen 1995; Lichtenberg, 1992). Multivariate studies find mixed evidence with regard to pre-bid abnormal stock returns: Palepu (1986) finds below-average returns, but Comment-Schwert (1995) find above-average returns. Nuttall (1999a,b) finds that the probability of takeover in the UK is decreasing in pre-bid performance, where 
performance is measured by Tobin's Q or profitability; similar conclusions are found in Bond-Meghir-Windmeijer (1998) and Dickerson-Gibson-Tsakalotos (1998). MorckShleifer-Vishny (1988; 1989) find evidence of underperformance for hostile takeover targets but not friendly takeover targets. However, Comment-Schwert (1997) for the US and Nuttall $(1999 \mathrm{a}, \mathrm{b})$ for the UK find no evidence of differences in pre-bid performance between hostile and friendly targets, whether measured in terms of operating profitability or Tobin's Q.

Studies of variations in takeover regulation exploit cross-sectional (Brook-HendershottLee, 1998; Schranz, 1993) or time-series (Schumann, 1988) variation in takeover regulation to infer the effect of the threat of takeover on company performance. The general finding of these studies is that regulations which make takeovers more costly tend to harm shareholders (Schumann, 1988), while takeover deregulation tends to benefit shareholders (Brook-Hendershott-Lee, 1998). These studies of takeover regulation add to our knowledge of the takeover process. However, they leave some questions unanswered. The cross-sectional studies do not tell us whether the threat of takeover has a one-off effect at deregulation, and then only a weak effect thereafter, or whether the effect is more enduring. Time series studies do not give us an idea of which firms are more likely than others to have performance altered by the threat of takeover.

Denis-Serrano (1996) and Denis-Denis-Sarin (1997a) study the effect of external corporate control events on corporate performance. Denis-Serrano (1996) find that management turnover in targets of unsuccessful control events is twice as high as in a matched random sample. Furthermore, the management turnover is concentrated among poorly performing firms and in firms in which outside blockholders acquire an ownership stake during the contest. Firms with a change in top management experience an increase in industry-adjusted operating profitability and in share price, and often these performance changes are associated with significant asset restructuring. DenisDenis-Sarin (1997a) find that firms which experience management turnover are almost twice as likely to have also experienced external corporate control activity as firms with no turnover, and where the corporate control activity is hostile, management 
turnover is more than twice as likely than in firms with no turnover. However, DannDeAngelo (1988) and Denis-Serrano (1996) find that managers often respond to the external corporate control threats by engaging in value-reducing defensive actions, such as a targeted repurchase of the bidder's shares ('greenmail') or changes in the asset and ownership structure of the target company. In summary, therefore, these papers provide an important insight into the channels through which external threats may impact upon internal monitoring, managerial behaviour, and company performance. However, they do not give us a direct overall measure of the strength of the effect of the takeover threat on company performance.

The only other study of which we are aware that directly measures the effect of the threat of takeover on company performance is Bond-Meghir-Windmeijer (1998), hereafter 'BMW'. These authors apply the same methodology as used in the current paper to a sample of 720 UK manufacturing companies over the period 1982-91 to study the effects of the threat of takeover on total factor productivity (TFP) and investment. They find that the twice-lagged predicted probability of takeover has a positive effect on TFP, but a negative effect on the investment rate. Thus their results and the results below are broadly consistent with each other, and the studies should be viewed as complementary. Possible advantages of the current study are as follows: unlike BMW, we distinguish between hostile and friendly takeover bids; the current study makes use of data on takeover speculation in the financial press to improve takeover prediction, and in general uses a less restrictive set of explanatory variables in the takeover likelihood model than BMW; unlike BMW, we examine a dividend model, in addition to TFP and investment models. BMW have a slightly earlier (and for some models, longer) sample period than the current study.

\section{Theories of the Threat of Takeover: Empirical predictions}

For theoretical surveys of how the takeover threat can impact upon managerial behaviour, see Milgrom-Roberts (1992) and Nickell (1995). For the purposes of deriving 
empirically testable predictions, we simplify somewhat by identifying just two views of the takeover threat: the disciplinary view; and the short-termism view. Below we draw out the implications of these views for the effect of the threat on our measures of company performance, namely total factor productivity (TFP), investment and dividends.

The disciplinary view takes the position that managers of modern widely-held corporations have considerable discretion in the allocation of effort, and in consequence that they enjoy large quasirents. The threat of acquisition by a hostile raider then acts as a spur to maximize value, since once the raider takes control the incumbent manager can expect to lose rents, either via job-loss or via suppressed discretion in the same job (Marris, 1963; Scharfstein 1988; Schmidt 1997). Of course to the extent that the incumbent manager expects to extract a financial payoff from the new owners the threat is less effective, though there is evidence that CEOs of target firms who lose their jobs generally fail to find another senior executive position in any public corporation within three years after the bid (Agrawal-Walkling 1994).

The disciplinary view predicts that an intensified takeover threat disciplines managers into raising asset productivity. This should be reflected in a TFP increase, possibly with a lag. In addition, an intensified takeover threat should lead the target manager to pay out greater dividends, as a means of returning free cash flow to shareholders (Myers 1998) and as a commitment device to value-maximizing behaviour (Zwiebel 1996). The implications of the disciplinary view for movements in investment depend on the form of the rents that the manager seeks, which in turn depends on the manager's preferences. If the manager has a preference for an 'easy life' then rent consumption may be associated with underinvestment, ${ }^{3}$ in which case a manager attempting to deter hostile takeover would raise investment. However, to the extent that the manager seeks rents in the form of wasteful acquisitions of other companies, or of diversification into unsynergistic product lines, then discretion is associated with overinvestment, in which case a disciplinary effect reduces investment (Jensen, 1986).

In contrast to the disciplinary view, the short-termism view argues that the threat

\footnotetext{
${ }^{3}$ For example, avoiding investing in a new cost-efficient technology.
} 
of takeover acts to damage long-term company performance. In the absence of perfect financial compensation after dismissal, an increased probability of job-loss raises the managerial discount rate and thus suboptimally reduces noncontractible investments, such as those in product quality or in good relations with the workforce (Laffont-Tirole, 1988; Shleifer-Summers, 1988). In addition, if managers have private information about the quality of the company, then an intensified takeover threat may encourage the manager to signal this information, either by paying out greater dividends (JohnWilliams, 1985) or by engaging in value-reducing asset sales (Stein 1988; BebchukStole 1993). ${ }^{4}$ Finally, the manager of a company subject to the threat of takeover might attempt to stave off a bid by undertaking value-reducing entrenchment activities that make him more costly to dismiss, such as instituting poison pills (Shleifer-Vishny, 1989) or diversifying into a product line in which the manager has specialized knowledge (Edlin-Stiglitz, 1995).

The short-termism view predicts that an intensified takeover threat leads to reduced investment but greater dividends. What are the implications for TFP? This depends on whether a lower investment level causes a fall in TFP. In a standard 'disembodiedknowledge' production function, productivity is unrelated to the investment level, provided that the level of the capital stock is correctly measured. However, if there are positive spillovers from new investment to productivity, for example via embodied technical progress, then reduced investment will lead to a fall in productivity; in this case the level of investment is directly related to the quality of the capital stock. The resolution to this question is therefore empirical. Greenwood-Hercowitz-Krusell (1997) and Hulten (1992) find an important role for investment-specific technical change in explaining post-war US productivity growth. However, as Temple (1998) points out, this evidence does not establish that investment causes TFP growth. There are other factors that can explain the positive association between investment and TFP growth, one of which is that when a new technology arrives it will generally raise both TFP and optimal investment. ${ }^{5}$ Therefore the empirical significance of the transmission mecha-

\footnotetext{
${ }^{4}$ In addition, Stein (1989) presents a signal-jamming model with similar (negative) implications for the effect of the takeover threat on long-term company performance.

${ }^{5}$ In a panel data study using UK company data, Nickell and Nicolitsas (1996) find a significant
} 
nism from investment to TFP growth is yet to be determined.

\section{Empirical Analysis}

Our sample is a panel of 643 UK quoted nonfinancial companies over the period 19891996, containing 108 friendly takeover bids and 49 hostile bids (see Table 1); see the Data Appendix for more details on the sample.

Accounting data on the companies over the period 1981-1996 were taken from Datastream International. Basic acquisition information was taken from the 1997 London Share Price Database. Information collected included the identity of firms that were acquired, dates of acquisition and company birth dates. Failed bids were identified using the Financial Times and the London Stock Exchange Quality of Markets Quarterly Review. In addition, information on takeover speculation was collected from the Financial Times; a unit observation was recorded for each article in which a sample company was touted as a potential takeover target. For the purpose of statistical analysis, these date-specific observations were aggregated into a yearly count for each company.

The Financial Times was also used to distinguish between hostile and friendly targets. Following Morck-Shleifer-Vishny (1988), we classify a hostile bid as one where the initial reaction by the target management was to resist the takeover. The two most important indications of a hostile takeover in the Financial Times were taken to be the incumbent management advising shareholders to reject the initial offer, or the incumbent management searching for a white knight. All other bids were classified as being friendly.

The empirical approach used in this paper is a two-stage one. In the first stage we construct measures of the intensity of the threat of takeover for each company in each year. In the second stage we assess how company performance varies with these measures.

Our measure of the intensity of the threat of takeover is the predicted probability of

role for R\&D expenditure in explaining investment, but no positive role for investment in explaining $\mathrm{R} \& \mathrm{D}$ expenditure. 
takeover obtained from a recursively-estimated takeover likelihood model. A takeover likelihood model is a model whose dependent variable indicates whether a given company is acquired or not in a particular year, and whose independent variables are a range of characteristics that we might expect to influence the probability of takeover. These models are standard in the finance literature ${ }^{6}$ and hence we restrict attention here to the key details; see Nuttall (1999a; 1999b) for a fuller analysis of the issues discussed in this section.

The basic model used is a logit model of the form

$$
\mathrm{BID}_{t+1}=f(\text { target characteristics } t)
$$

where $\mathrm{BID}_{t+1}$ is a discrete variable that takes the value one if the company is the subject of a takeover bid in accounting year $t+1$, and takes the value zero otherwise. When we examine multinomial exit models, the dependent variable can take strictly positive integer values greater than one, depending on the number of event types.

Following extensive experimentation with a list of candidate independent variables, our preferred specification comprises: company size (measured by log capital stock), performance (return-on-sales and Tobin's Q), capital structure and financial pressure (measured by leverage and income gearing), company age since listing, incidence of takeover speculation, stock market-wide takeover activity and a business cycle measure. ${ }^{7}$

We wish to use our takeover likelihood models to gain insight into a manager's expectation at any point in time that she will be the subject of a takeover bid in the future, and in particular to construct a quantitative measure of the ex ante threat of takeover. ${ }^{8}$ Hence it seems preferable to use only public information that pre-dates the bid, since this information actually was historically available to the manager. Accordingly, if we are estimating predicted takeover probabilities for year $t+1$, we use only

\footnotetext{
${ }^{6}$ See for example Palepu (1986), Morck-Shleifer-Vishny $(1988 ; 1989)$ and Comment-Schwert (1995; 1997).

${ }^{7}$ See the Data Appendix for definitions of all variables used in this paper.

${ }^{8}$ This is distinct from the motivation in the existing literature, which is to examine ex post the determinants of takeover likelihood; namely to understand why some firms were taken over and others were not.
} 
accounting and other information that was available at year $t$, both as the explanatory variables and in the estimation of the model's coefficients. Hence the estimation proceeds recursively, with the probability of being acquired in year $t$ being predicted using marginal effects that are estimated using data pooled over the period from 1988 to $t-1$, where $t=1989,1990, \ldots, 1996 .^{9}$

In a model used to estimate the probability of future takeover, such as a recursive model, it does not seem sensible to use year dummies to control for aggregate influences. To see this, consider for example the case where we wish to estimate the predicted probability of a company being acquired in 1993, using information up to and including 1992. It would be possible to estimate the model using year dummies up to 1992, and to use this model to estimate takeover probabilities for 1993, (implicitly) setting the 1993 year dummy to zero. However, this is probably less sensible than excluding the year dummies altogether. The reason is that for the sample period up to 1992 we would estimate coefficients that are conditional on allowing for year effects. These would be the correct coefficients for forecasting if we knew (or could estimate) the 'right' coefficient on the year dummy for 1993, but not otherwise. Of course it might be possible to forecast explicitly what the coefficient on the 1993 year dummy could be expected to be, using information available up to 1992, but this seems a long-winded exercise. In consequence we do not use year dummies in the recursive model $;{ }^{10}$ instead, to capture time-related shocks, we experimented with a variety of observed macroeconomic variables. With regard to economic activity, these included unemployment, GDP, interest rates, the Retail Price Index, and an aggregate wage index. With regard to stock market activity these included the aggregate number of takeovers on the London Stock Exchange as a whole and the industry-specific number of takeovers on the London Stock Exchange (measured at the 2-digit level). The two macro variables which we found to have greatest explanatory power were the lagged aggregate number of takeovers on the London Stock Exchange as a whole, and lagged

\footnotetext{
${ }^{9}$ This is similar in methodology to the Pesaran-Timmermann (1995) analysis of forecasting stock price movements.

${ }^{10}$ Also, we do not include industry dummies, since they were found to be individually and jointly insignificant whether measured at the 2-digit SIC level or at a more aggregated 15-sector level.
} 
real GDP growth. The former variable might be expected to capture a 'merger wave' effect, while the latter might capture a business cycle effect. These variables were included directly in the recursively-estimated takeover likelihood models.

Table 2 reports the results for a multinomial model where the event routes are hostile bid and friendly bid, estimated over the full sample period 1989-96. We report the marginal effects (computed at the averages of the explanatory variables) rather than the coefficients, since the marginal effects and the coefficients for multinomial logit models (which are nonlinear) will generally differ; indeed they need not have the same sign. ${ }^{11}$ From Table 2 we see that the probability of a friendly bid is: decreasing in target size, Tobin's Q and company age since listing; increasing in leverage, the incidence of takeover speculation concerning the target, stock market-wide merger activity and economic activity. The probability of a hostile bid is: decreasing in Tobin's Q, company age since listing and sectoral income gearing; increasing in the incidence of takeover speculation concerning the target, stock market-wide merger activity and economic activity.

A Wald test rejects at the $5 \%$ level the null hypothesis that the marginal effects are jointly equal across friendly and hostile takeovers is strongly rejected. Further Wald tests reveal that this difference is driven by the age variables, though size, leverage and takeover rumours are also individually significantly different across the takeover types at the $6 \%$ level. That is to say, being stock market-young, small, highly leveraged or touted as a takeover target in the financial press has a much stronger positive impact on the probability of being friendly-acquired than on the likelihood of being hostileacquired. We find that both hostile and friendly targets have poor pre-bid performance (as measured by Tobin's Q), although there is no evidence of performance differences across the two target types. ${ }^{12}$

Table 3 provides summary statistics on the predicted probabilities. In order to assess the predictive accuracy of our takeover likelihood models, we would like to see whether it is the case that groups of observations with a high predicted probability of

\footnotetext{
${ }^{11}$ See Greene (1997, Ch.19) for a discussion.

${ }^{12}$ This latter finding is consistent with Comment-Schwert (1997).
} 
being the subject of a takeover bid in the following accounting year actually have a high sample frequency of being the subject of a takeover bid in the following accounting year. In order to do this, we rank the observations for each year in decreasing order of predicted probability. Then we observe whether there is a higher sample frequency at the top of the distribution of predicted probabilities than at the bottom.

Table 4.1 takes predicted probabilities of hostile takeover occurring in 1989, implied by the multinomial logit model estimated recursively (ie, using the set of explanatory variables for 1988 only). There are 579 observations and 16 hostile bids. We see that of the ten companies with the highest predicted probability of a bid, 3 were actually the subject of a hostile takeover bid in 1989. This compares with zero actual bids in the ten companies with the lowest predicted probability of a bid, and with 0.28 if the actual hostile bids were evenly distributed across the observations (that is, if we use a zero-information model to predict hostile takeover target events). In the top half of the ranked observations there were seven times more actual takeovers in the subsequent year than in the bottom half; for a zero-information model this number would be one.

For purposes of comparison over time, Table 4.2 reports the top half/bottom half figures for 1989-96. We see that the top/bottom ratio varies year-by-year, but is greater than one in all years except 1994 and 1996. We found similarly that the predicted probabilities of friendly takeover or of either kind of takeover also exhibited significant forecasting power in the sense that they identify firms that were actually subsequently acquired much more successfully than a zero-information model does. ${ }^{13}$ Given that our recursive models are based only on publicly- and historically-available information, it seems reasonable therefore to use the predicted probability of takeover as a measure of the intensity of the threat of takeover. The next section describes how we make use of the predicted probabilities in models of corporate performance.

\footnotetext{
${ }^{13}$ See Nuttall (1999b) for details.
} 


\section{$5 \quad$ Performance Models}

The second stage of the analysis involves using the predicted probabilities as an explanatory variable in econometric models of company performance. Our performance variables are total factor productivity, investment and the dividend payout ratio. We estimate each of the performance models below using the panel-data GMM system estimator proposed by Arellano and Bover (1995) and Blundell and Bond (1998). ${ }^{14}$ This estimator uses lagged first differences of the series as instruments for equations in levels, in addition to the now-standard use of lagged levels as instruments for the equations in first differences (initially proposed by Arellano and Bond, 1991).

Blundell and Bond (1998) find that the system estimator offers substantial efficiency gains and lower finite-sample biases in situations where the first differenced estimator performs poorly, notably where first-differences are only weakly correlated with the lagged levels of the series and where the number of time series observations is moderately small. The validity of the additional instruments depends on a stationarity restriction, which can be tested using standard tests of over-identifying restrictions.

We report results for a one-step GMM estimator, for which inference based on the asymptotic variance matrix has been found to be more reliable than for the (asymptotically) more efficient two-step estimator (Blundell and Bond, 1998).

Denoting by $p_{i t}$ the constructed probability of firm $i$ being taken over in year $t+1$, our performance models have the form

$$
y_{i t}=\beta x_{i t}+\gamma p_{i t}+\left(\eta_{i}+\varepsilon_{i t}\right)
$$

where $\eta_{i}$ is an unobserved firm-specific effect, $\varepsilon_{i t}$ is a serially uncorrelated error term, and $x_{i t}$ includes all the remaining explanatory variables that we control for. We also experiment with lags of $p_{i t}$ in the specifications. The corresponding equations in first differences are

$$
\Delta y_{i t}=\beta \Delta x_{i t}+\gamma \Delta p_{i t}+\Delta \varepsilon_{i t}
$$

Noting that $p_{i t}$ is constructed using information from period $t$, we treat $p_{i t}$ as

\footnotetext{
${ }^{14}$ Estimation was performed using DPD98 (Arellano-Bond 1998).
} 
an endogenous variable in these models (ie, potentially correlated with $\varepsilon_{i t}$ ), and thus instrument $p_{i t}$ using $p_{i t-2}$ and further lags for the equations in first-differences, and using $\Delta p_{i t-1}$ for the equations in levels. We describe for each model below the instrument set used for the remaining regressors. Instrument validity is tested using tests of second-order serial correlation in the first-differenced residuals and Sargan tests of over-identifying restrictions (see Arellano-Bond 1991 for details).

Pagan (1984) develops an econometric framework for two-stage estimation with generated regressors; that is, where a structural equation (here, the performance model) includes regressors that are generated in an auxiliary equation (here, the takeover likelihood model). Pagan (1984, Theorem 3) establishes that if the null hypothesis to be tested is that the generated regressor has a coefficient of zero in the structural equation (that is, $\gamma=0$ in our performance models above) then the two-stage estimation procedure with generated regressors that we use here is valid. Newey (1984) shows that this result extends to a GMM framework. Under the alternative hypothesis that $\gamma \neq 0$, the estimated coefficients remain consistent, though the standard errors should be adjusted to reflect dependence across observations. Since our primary interest is to test the null hypothesis that takeover risk has no impact on company performance, we have not implemented this correction here. Such corrections are generally found to be very small in similar applications.

For each performance model we report results for predicted probabilities constructed from a multinomial takeover likelihood model with two possible exit routes: (successful) friendly takeover and (successful) hostile takeover.

We also report results for the probability of either kind of takeover (the aggregate probability $p_{i t}^{A}$ ), which is just the sum of the probability of hostile takeover $\left(p_{i t}^{H}\right)$ and friendly takeover $\left(p_{i t}^{F}\right)$ taken from the multinomial model. We experimented with both the probability levels $p_{i t}$ and the first-differences $\Delta p_{i t}$ in order to distinguish between transient and permanent effects: the levels effect always dominates so we report only the levels coefficients.

As a robustness check, for each model below we experimented with variations on 
the baseline takeover likelihood model used to generate the probabilities. For example we varied the dependent variable between takeover target and successful acquisition, and we examined variations in the logit regressors (for example, different measures of company size and dropping sectoral variables). We also considered constructing the probabilities using both full-sample and recursive estimates of the logit coefficients. For all these variations the results were qualitatively similar.

Since our sample companies are drawn without replacement from a population alive in 1988, our panel dataset experiences some attrition over time. A potential concern is that our estimation of Eqn.(2) may be biased if the attrition from the sample is endogenous in the sense that the probability of exiting the sample is correlated with the shocks to the performance model $\varepsilon_{i t} .{ }^{15}$ In general it will be difficult to distinguish between the structural effect of the takeover probabilities on performance and the effects of attrition bias since the selectivity correction term that we would need to include in Eqn. (2) to correct for attrition would be highly correlated with the takeover probabilities $p_{i t}$. Formally, therefore, we should think of the takeover probabilities in the performance model as testing the joint null hypothesis that $p_{i t}$ has no effect on measures of performance (namely, $\gamma=0$ ) and that the attrition process is exogenous for the performance equation.

One rather strong assumption that makes the attrition process exogenous for the performance equation is if the exit process does not depend on performance at all (that is, performance does not affect the probability of being acquired). A somewhat weaker assumption would be that the exit process does not depend on the error term $\varepsilon_{i t}$ in the performance equation, which would follow if the influences on performance that are unobservable to the econometrician (that is, $\varepsilon_{i t}$ ) are also unobservable to potential bidders (in which case they could not influence the probability of exit).

We turn now to the specification of and results from our three performance models. All interpretations of the findings are discussed in Section 6.

\footnotetext{
${ }^{15}$ Correlation with the fixed effects $\eta_{i}$ is unproblematic, since the fixed effects are differenced out in the estimation procedure.
} 


\subsection{Total Factor Productivity}

We use a Cobb-Douglas autoregressive distributed lag (ADL) panel data model of the form

$$
\begin{aligned}
y_{i t}= & \alpha_{t}+\rho y_{i t-1}+\beta_{0} l_{i t}+\beta_{1} l_{i t-1}+\delta_{0} k_{i t}+\delta_{1} k_{i t-1} \\
& +\gamma_{0} p_{i t}+\gamma_{1} p_{i t-1}+\gamma_{2} p_{i t-2}+\left(\eta_{i}+\varepsilon_{i t}\right)
\end{aligned}
$$

where $y_{i t}$ is $\log$ real sales of firm $i$ in year $t, l_{i t}$ is $\log$ employment, $k_{i t}$ is log real capital stock, $p_{i t}$ is the estimated probability of firm $i$ being taken over in year $t+$ 1 given information available at year $t$, and $\alpha_{t}$ is a year-specific intercept. Of the error components, $\eta_{i}$ is an unobserved firm-specific fixed effect and $\varepsilon_{i t}$ is a serially uncorrelated error term.

The simple ADL dynamics are intended to capture the fact that whenever factors of production are changed, it typically takes time for output to reach its new longrun level. For example, an increase in the threat of takeover may take time to affect corporate decisions, and hence output; we experiment with lags of up to two years in the probabilities.

We maintain that $l_{i t}, k_{i t}$, and $p_{i t}$ are potentially correlated with $\eta_{i}$ and $v_{i t}$, and hence we treat labour, capital and the takeover probabilities as endogenous. In addition, the lagged dependent variable allows for endogenous persistence. The assumption that the error term is serially uncorrelated generates moment conditions that allow the use of suitably lagged levels of the variables as instruments, after the equation has been differenced to eliminate the firm-specific effects (Arellano-Bond, 1991). If we are willing to assume that the first-differences of the endogenous variables are uncorrelated with the firm-specific effect, then we obtain additional moment conditions that allow the use of suitably lagged first differences of the variables as instruments for the equations in levels (see Arellano-Bover, 1995). For an AR(1) model, Blundell-Bond (1998) show that there can be dramatic improvements in finite sample bias and efficiency from exploiting additional moment conditions of this type, particularly in cases where the instruments available for the first-differenced equations are weak. Blundell-Bond (1997) find that this estimator works well in the context of production functions. 
Table 5 presents our production function results. ${ }^{16}$ Column 1 estimates a basic production function, without the takeover probabilities. The coefficients on the capital and labour variables are similar to those obtained in other recent production function studies-see Nickell (1996) for the UK and Blundell-Bond (1997) for the US. The longrun elasticities on labour and capital are 0.43 and 0.32 respectively; the $\mathrm{P}$-value on the test statistic for the null hypothesis of constant returns to scale was found to be 0.26 , so we do not reject the null. ${ }^{17}$

With serially uncorrelated errors in the levels equations, we expect to find negative first-order serial correlation in the first-differenced errors; indeed all our results reveal strong negative first-order serial correlation (m1). However, the consistency of the GMM estimators relies on the assumption of zero second-order serial correlation in the first-differenced errors. Table 5 illustrates that this assumption is satisfied in our production function estimates $(\mathrm{m} 2)$. Unlike with the serial correlation test, no robust Sargan test based on the one-step estimates is available; hence we report the Sargan test based on the corresponding two-step GMM estimator. This test does not reject our instrument sets.

Table 5 (Column 2) adds the lagged probability of friendly takeover to the basic production function, and finds a positive and significant coefficient. This effect appears to operate through the first-lag only; the current and twice-lagged probabilities were found to be insignificant, whether included together or separately. Column 3 finds that the coefficient on the probability of hostile takeover is positive but insignificant. When both probabilities are included in the specification (Column 4), the friendly risk remains positive and significant (at the $12 \%$ level), and the hostile risk remains statistically indistinguishable from zero. However, we found that a hypothesis test cannot reject the null hypothesis of equal coefficients on the friendly and hostile probabilities. ${ }^{18}$

\footnotetext{
${ }^{16}$ Because we require a minimum of three observations on each company for the first-differenced equations used in the system-GMM estimator, this reduces the sample available to estimate the production function to 551 firms, as reported in Table 5 .

${ }^{17}$ The hypothesis of constant returns to labour and capital is also accepted for specifications of the production function that include the takeover probabilities. For example, for the specification in Column 2 of Table 5, the P-value on the test statistic is 0.78, and for that in Column 5 of Table 5 is 0.19 .

${ }^{18}$ The P-value on the test statistic for the null hypothesis of equal coefficients on the friendly and
} 
Column 5 of Table 5 finds that the lagged overall probability of takeover (that is, the probability of either hostile or friendly takeover) has a positive effect on productivity, with a P-value of 0.02 .

The long-run elasticity on the aggregate takeover risk is 1.4086 (from Table 5, Column 5). Thus our results imply that an increase in the aggregate probability of takeover by $5 \%$ (which is roughly one standard deviation-see Table 3) raises total factor productivity by approximately $7.0 \%$.

What do these results tell us about the effect of the probability of takeover on productivity? First of all, looking at the overall probability, there is evidence that an intensification of takeover risk raises productivity after a lag of one accounting year. Dividing by takeover type, however, it appears that the statistical significance of this effect is entirely driven by the friendly risk. The lagged hostile risk is statistically indistinguishable from either the friendly risk or from zero. This result on the friendly/hostile effects is consistent with two hypotheses. First, hostile and friendly takeover probabilities have the same effect on productivity, but because of the smaller number of hostile takeovers than friendly takeovers, this effect is identified only through the friendly channel. Secondly, the threat of hostile takeover genuinely has no effect on productivity, whereas the friendly risk really does raise productivity. We shall have more to say on these hypotheses once we have examined the investment and dividend models.

\subsubsection{Robustness}

In this section we investigate some variations on the baseline specification of Table 5, in order to assess to what extent our findings above are robust.

First we consider an identification problem that is general to two-stage regression models. Suppose that our baseline performance model were perfectly specified except for not taking into account the threat of takeover. Then we would be confident that including measures of the threat of takeover as regressors in the performance model would tell us purely about the threat of takeover, and not about any other omitted hostile probabilities is 0.20 . 
variable. However, there is little reason to believe that our performance models are perfectly specified. In this context it is possible, therefore, that our takeover probabilities, which are (nonlinear) combinations of the independent variables used in the logit takeover likelihood model, are simply capturing the effect of these logit regressors on performance. ${ }^{19}$

The ideal way to test this omitted variable bias in our models would be to enter the logit regressors on the right-hand side of the performance models, and to test the (nonlinear) restriction imposed by the takeover probabilities. However, this is not straightforward to implement. We adopt the simpler approach of including on the right-hand side some of the key logit regressors (Tobin's Q, leverage, takeover rumours and age) and testing whether the takeover probabilities remain significant. Provided we include the logit regressors at the same lag as the probabilities, this will give us some indication of whether the probabilities are significant only because of spurious (linear) correlation with the key logit regressors.

Table 6 takes a baseline specification including the lagged probability of overall takeover, and adds in one at a time the key logit regressors lagged $\mathrm{Q}$, leverage, rumours and age-and finally all of these variables together in Column 5. The main point to notice from Table 6 is that the significance of the aggregate probability is robust to the addition of these logit regressors.

Column (1) shows that $\mathrm{Q}$ is insignificant, although the inclusion of $\mathrm{Q}$ leaves the effect of capital in the production function poorly determined. Lagged leverage is the most significant of the logit regressors, and has a positive effect on productivity. This is consistent with Nickell-Wadhwani-Wall (1992), who find that higher levels of debt are

\footnotetext{
${ }^{19}$ One example of this identification problem arises in the literature on financial constraints. The methodology of this literature is to examine whether there is a significant effect of cash flow on investment. If such an effect exists then it is consistent with the hypothesis that there exist financial constraints that drive a wedge between the internal and external cost of capital, since under these conditions a windfall increase in profits relaxes the constraints, and allows more positive-NPV investment projects to be financed. If the investment model were perfectly specified, then it would indeed be possible to interpret the significant cash flow coefficient as a financial constraint effect. However, as noted by Gilchrist-Himmelberg (1995), if the investment model is imperfectly specified (as it almost certainly is in practice) then a significant cash flow effect is also consistent with the hypothesis that information on cash flow helps to forecast omitted variables that explain investment spending, such as future output.
} 
associated with higher levels of productivity. One possible explanation is that financial pressure reduces managerial slack and thus raises productivity, as discussed in Section 3.

Lagged rumours have a negative but insignificant $(\mathrm{P}=0.12)$ effect on TFP, conditional upon the takeover probability (Table 6, Column 3). However, we found that this effect disappears in the full specification of Column 5 of Table 6 , or if we removed the probability from the specification. This provides weak evidence for a 'subjective' effect of rumours, in addition to the objective effect mediated through the takeover probabilities. Rumours themselves appear to be too crude a measure of the risk of takeover to be informative about productivity in isolation. However, when combined with other explanatory variables in a takeover likelihood model, a positive objective effect of takeover risk emerges. In addition, conditional upon this objective effect, the incidence of rumours in the press has a weak negative effect on performance.

Lagged age since listing is insignificant in the production function. To summarize, therefore, the positive effect on productivity of the lagged probability of takeover appears to be robust to the inclusion of the regressors which drive our takeover likelihood models. This is evidence against the view that the takeover probabilities are significant purely because they are spuriously correlated with the omitted explanatory variables from the production function. 


\subsection{The Investment Model}

Following Bean (1981) and Bond-Elston-Mairesse-Mulkay (1997), our investment model is based on the error correction form: ${ }^{20}$

$$
\begin{aligned}
\left(\frac{I_{i t}}{K_{i t-1}}\right)= & \alpha_{t}+\rho\left(\frac{I_{i t-1}}{K_{i t-2}}\right)+\beta_{0} \Delta y_{i t}+\beta_{1} \Delta y_{i t-1} \\
& -\phi\left(k_{i t-2}-y_{i t-2}\right)+\theta y_{i t-2}+\delta_{0}\left(\frac{C_{i t}}{K_{i t-1}}\right)+\delta_{1}\left(\frac{C_{i t-1}}{K_{i t-2}}\right) \\
& +\gamma_{0} p_{i t}+\gamma_{1} p_{i t-1}+\gamma_{2} p_{i t-2}+\left(\eta_{i}+\varepsilon_{i t}\right)
\end{aligned}
$$

where $I_{i t}$ is investment and $C_{i t}$ is cash flow. This error correction model (ECM) is based on a long-run demand for capital equation

$$
k_{i t}=a_{t}+y_{i t}
$$

where $a_{t}$ is a time effect, with additional terms testing for non-constant returns to scale, cash flow effects and effects from the probability of takeover. Note that the inclusion of time effects will control for the common effect of prices and interest rates on the demand for capital. Equation (6) holds if either: (a) we have constant returns in a CES technology; (b) we have Cobb-Douglas technology with any returns to scale. If this proportionality holds in the ECM (5) then $\theta=0$.

Table 7 presents our investment equation results. ${ }^{21}$ The results are in line with what we would expect for an ECM investment model. Current and lagged changes in output have a very significant and positive effect on current investment, supporting the model's assumption that the demand for capital is increasing in output. The error correction term is negative and highly significant, so that a capital stock above its

\footnotetext{
${ }^{20}$ With regard to the econometric modelling of investment, there are three main approaches in addition to the error correction model: the accelerator model; the Q model; and the Euler Equation approach. The error correction model encompasses accelerator and partial adjustment models (BondElston-Mairesse-Mulkay, 1997). The main problem with the Q model is empirical: studies tend to find that whilst $\mathrm{Q}$ is a significant factor in the explanation of company investment, its effect is small, and the prediction of Q theory, that Q should be a sufficient statistic for investment, is generally rejected (Blundell-Bond-Devereux-Schiantarelli, 1992). Finally, Nickell-Nicolitsas (1996) question the robustness of the Euler Equation approach, on the grounds that estimated Euler equations often have coefficients which are inconsistent with an Euler equation interpretation. Given this fragility of structural investment models, we choose to work with a flexible error correction specification of a reduced form model.

${ }^{21}$ Here we require a minimum of four observations on each company.
} 
desired level is associated with lower future investment, and vice versa. Twice-lagged output is significant but small in magnitude, indicating some violation of constantreturns-to-scale, but not to a great extent. In addition, the lagged cash flow term has a positive and weakly significant effect on current investment, ${ }^{22}$ though current and twice-lagged cash flow were found to be insignificant.

Column 1 of Table 7 shows that the lagged probability of friendly takeover has a strongly negative effect on investment; there was found to be no effect of the current or twice-lagged probability. We find that the hostile probability also has a negative effect, and is significant at the $7 \%$ level; however, the effect was found to operate only through the second lag. The significance of this effect is enhanced when we enter both probabilities in the investment model (Table 7, Column 3). That is, conditional upon the lagged friendly risk, the twice-lagged hostile risk is found to have an even stronger negative effect on investment. These effects show through in the aggregate takeover risk, which has a negative coefficient at both first and second lags, though is more significant at the first lag (Table 7, Column 4).

The long-run elasticity on the aggregate takeover risk is -0.3482 (from Table 7 , Column 4). Hence a $5 \%$ increase in the aggregate probability of takeover would be expected to reduce investment by approximately $1.7 \%$.

This evidence suggests that in fact the hostile probability does contain information distinct from the friendly probability. This remains the case when, in Table 8 , we add in the key logit regressors (analogously to Table 6). We include both first- and secondlags of the logit regressors, in order to detect whether either the friendly or hostile probability is having a spurious effect. As Table 8 shows, both hostile and friendly probabilities retain their sign and significance when the logit regressors are included. In fact the only logit regressor that is significant is Tobin's Q, which affects investment positively, as we would expect. Note, however, that the coefficient on Q is tiny, and the sufficient statistic prediction is rejected. This is broadly consistent with other econometric studies of investment, finding that the Q effect is typically significant but

\footnotetext{
${ }^{22}$ The P-values on the lagged cash flow coefficient for the specifications in Table 7 range between 0.06 and 0.16 .
} 
small (Blundell-Bond-Devereux-Schiantarelli, 1992). One further interesting finding is that the inclusion of $\mathrm{Q}$ in the error correction specification leaves the cash flow variable insignificant, ${ }^{23}$ suggesting that cash flow may be proxying for expected future demand, rather than reflecting the impact of financial constraints. Indeed the cash flow variable is also rendered insignificant by the inclusion of leverage, rumours or age in the specification. Thus in our data the effect of cash flow on investment is weak and nonrobust.

\subsection{The Dividend Model}

To motivate our dividend model, we begin with a simple Lintner (1956) type model where dividends depend on the normal or trend level of earnings. ${ }^{24}$ We begin with a long-run specification for dividends as follows:

$$
D_{i t}=\lambda+\beta \pi_{i t}+u_{i t}
$$

where $D$ is the level of dividends, $\pi$ is net profits and $u_{i t}$ is a mean-zero error term that may be heteroskedastic.

To reduce the impact of heteroskedasticity, we divide through by a measure of company size (here we choose sales revenue $Y$ ), which gives us

$$
\left(\frac{D}{Y}\right)_{i t}=\frac{\lambda}{Y_{i t}}+\beta\left(\frac{\pi}{Y}\right)_{i t}+e_{i t}
$$

where $e_{i t}=\frac{u_{i t}}{Y_{i t}}$. For example, in the special case where the variance of $u_{i t}$ is proportional to company size, that is

$$
u_{i t}=Y_{i t} \varepsilon_{i t}, \varepsilon_{i t} \sim \operatorname{IID}\left(0, \sigma_{\varepsilon}^{2}\right)
$$

then this scaling would remove the heteroskedasticity entirely: $e_{i t}=\varepsilon_{i t}$. More generally we do not expect that this scaling will completely eliminate heteroskedasticity, but

\footnotetext{
${ }^{23}$ This was also found to be the case in the same specification except omitting the takeover probabilities.

${ }^{24}$ Empirical support for the Linter model was found by Fama and Babiak (1968). More recently, Campbell and Shiller (1988) and DeAngelo, DeAngelo and Skinner (1992) report evidence that is broadly consistent with the Lintner model. Campbell-Shiller (1988) find that a long historical average of real earnings is a good predictor of the present value of future real dividends. DeAngelo, DeAngelo and Skinner (1992) find that dividend reductions are more likely given greater current losses and more persistent earnings difficulties.
} 
initial experiments with an unscaled specification suggested that the reduction was substantial.

To allow for inertia and persistence, we introduce ADL dynamics. For example, if $e_{i t}$ in (8) has an $\operatorname{AR}(1)$ process $\left(e_{i t}=\rho e_{i t-1}+v_{i t}\right)$ we would obtain:

$$
\left(\frac{D}{Y}\right)_{i t}=\rho\left(\frac{D}{Y}\right)_{i t-1}+\frac{\lambda}{Y_{i t}}-\rho \frac{\lambda}{Y_{i t-1}}+\beta\left(\frac{\pi}{Y}\right)_{i t}-\rho \beta\left(\frac{\pi}{Y}\right)_{i t-1}+v_{i t}
$$

However, we do not impose the common factor restrictions, but rather we estimate the unrestricted specification:

$$
\left(\frac{D}{Y}\right)_{i t}=\theta_{1}\left(\frac{D}{Y}\right)_{i t-1}+\frac{\theta_{2}}{Y_{i t}}+\frac{\theta_{3}}{Y_{i t-1}}+\theta_{4}\left(\frac{\pi}{Y}\right)_{i t}+\theta_{5}\left(\frac{\pi}{Y}\right)_{i t-1}+v_{i t}
$$

Finally we allow for time effects and firm effects, specifying $v_{i t}$ to have the errorcomponents form $v_{i t}=\alpha_{t}+\eta_{i}+\nu_{i t}$, and we introduce the takeover probabilities: ${ }^{25}$

$$
\begin{aligned}
\left(\frac{D}{Y}\right)_{i t}= & \alpha_{t}+\theta_{1}\left(\frac{D}{Y}\right)_{i t-1}+\frac{\theta_{2}}{Y_{i t}}+\frac{\theta_{3}}{Y_{i t-1}}+\theta_{4}\left(\frac{\pi}{Y}\right)_{i t}+\theta_{5}\left(\frac{\pi}{Y}\right)_{i t-1} \\
& +\gamma_{0} p_{i t}+\gamma_{1} p_{i t-1}+\gamma_{2} p_{i t-2}+\left(\eta_{i}+\nu_{i t}\right)
\end{aligned}
$$

Table 9 presents results for our dividend model. We found that the coefficients $\theta_{2}$ and $\theta_{3}$ were individually and jointly insignificant, and that omitting them did not affect the other coefficients in (12). In addition, we found that company age since listing is always highly significant when included as an additional regressor in (12), with older firms tending to have higher dividend payout ratios. Hence we omit the size terms from our baseline dividend model specification, but we include age in all the reported results.

Tables 8 and 9 show that the lagged dependent variable is positive and significant. Current profits has a strongly positive effect on dividends, though the first- and secondlag were found to be insignificant, and were thus omitted from the specification. ${ }^{26}$

\footnotetext{
${ }^{25}$ Bond-Chennells-Devereux (1996) use a specification similar to (12) to investigate the effect of taxes on dividend policy. However, we are not aware of any papers that attempt explicitly to derive a dividend model of the form in (12).

Using aggregate time series data, Feldstein (1970) and Poterba (1987) estimate an error-correction specification based upon a long-run equation similar to (7); the dependent variable in their models is the change in the logarithm of real dividends. This approach cannot be used with company data, since at the firm level dividends can be zero and profits can be negative.

${ }^{26}$ The measure of profits we use here is accounting profits net of interest, taxes and depreciation. However, we also experimented with cash flow and found very similar results. See the Data Appendix for definitions of these variables.
} 
Column 1 of Table 9 shows that the dividend payout ratio is increasing in the current aggregate probability of takeover. However, the coefficient is not well-determined $(\mathrm{P}=0.14)$, and becomes even less well-determined when we remove the lagged probability in Column 2.

We find that the current probability of hostile takeover has a positive and highly significant effect on dividend payout (Table 9, Column 3). We found that this effect operates entirely through the current hostile risk: there was no effect at the first and second lags. The long-run elasticity on the hostile takeover risk is 0.7764 (from Table 9, Column 3). Thus our results imply that an increase in the probability of hostile takeover by $3 \%$ (which is roughly one standard deviation-see Table 3) raises the dividend-to-sales ratio by approximately $2.3 \%$.

The lagged probability of friendly takeover has a negative but insignificant effect on dividend payout (Table 9, Column 4), and this effect becomes even less significant when we include the current hostile risk (Table 9, Column 5). This provides further evidence that the hostile risk contains information distinct from the friendly risk, in spite of the smaller number of hostile takeovers.

On the basis of the results in Table 9, our preferred specification for the dividend model is that of Column 3. Table 10 tests for the robustness of this specification to the key logit regressors. We find no effect of Tobin's Q or leverage on dividends, but takeover rumours have a negative effect on dividend payout (Table 10, Columns 3 and 4). However, this effect disappears if we omit the probability of hostile takeover from the specification. Hence rumours appear to have a negative 'subjective' effect on dividend payout, conditional upon the probability of takeover (which of course already incorporates an objective measure of the effect of rumours on takeover likelihood).

\section{Discussion of findings}

Let us summarize the main findings above. Taking first the aggregate probability of takeover, we find that the lagged probability has a significantly positive effect on productivity and a significantly negative effect on investment. The current probability 
of takeover has a positive but insignificant effect on dividend payout.

Turning to the distinction between hostile and friendly takeover risk, we find that the hostile risk appears to have no effect on productivity, but has a positive and highly significant effect on current dividend payout, and a negative and significant effect on investment with a lag of two accounting years.

The friendly takeover risk has a lagged positive effect on productivity and a lagged negative effect on investment. However, dividend payout is not significantly affected by friendly risk.

These effects are robust to the inclusion of the key logit regressors on the right-hand side on the performance models. The effects for a given risk type (friendly or hostile) are robust to the inclusion of the other risk type as a regressor.

What do these results suggest about theories of takeover? First of all, consider the evidence on the aggregate takeover risk. This evidence is consistent with a Jensen free cash flow view whereby the threat of takeover reigns in managerial overinvestment and leads to better company performance, as reflected in the subsequent productivity improvement. The weak positive effect of the aggregate risk on dividend payout could arise because the takeover threat forces the manager to return current excess cash to shareholders or because the manager wishes to commit to reduced shirking in the future, as in Zwiebel (1996).

This story does indeed nicely explain the findings on the effects of the aggregate probability. However, when we examine the distinction between hostile and friendly takeover risk, matters become less clear. Note that our evidence above suggests that the predicted probabilities of friendly and hostile takeover contain distinct information. This follows from the investment and dividends equations, where the effect of hostile takeover risk is statistically distinguishable both from zero and from the effect of the friendly takeover risk.

Consider the hostile probabilities first. The results here appear to be consistent with two very different stories of the underlying mechanism of the market for corporate control. First, the Jensen view, as explained for the aggregate probability. Second, a 
short-termism view. Let us consider these possible explanations in more detail.

The support for the Jensen view of hostile takeovers would be as follows. The negative effect of the threat of hostile takeover on subsequent investment reflects the reigning in of managerial empire-building. The strongly positive effect on current dividends reflects the reduction in investment spending, the returning of free cash flow to the shareholders and possibly the improvements in performance resulting from improved managerial discipline. This last point follows from the evidence that dividend announcements are associated with abnormal stock returns (Aharony-Swary, 1980; Asquith-Mullins, 1983). With regard to the productivity effects, this explanation would emphasize the finding that the hostile probability is insignificantly different from the friendly probability, which is itself positive. In addition, the threat of hostile takeover can affect productivity through two channels: a direct disciplinary effect; and an indirect effect that operates via the investment rate, for example if technical progress is partially embodied in capital. If we believe in a role for embodied technological change, then the indirect effect is negative for the hostile risk (since hostile risk reduces subsequent investment). Since the overall observed effect of hostile risk on TFP is neutral, this implies that the direct disciplinary effect must be positive.

There are two problems with this Jensen explanation. First, while it is welldocumented that companies that initiate (or raise) dividends experience share price increases (Aharony-Swary, 1980; Asquith-Mullins, 1983), current dividend changes do not help to predict firms' future earnings (DeAngelo-DeAngelo-Skinner, 1996; BenartziMichaely-Thaler, 1997). Thus it is an open question as to whether dividends are a good performance measure.

Second, and more problematic, is the finding that the hostile risk has no effect on productivity. If indeed the threat of hostile takeover is having a strong Jensen effect, we would expect this to be reflected in clear productivity improvements at some point, but we find no evidence of this. To the extent that technical progress is embodied in capital, this may not be damaging to the Jensen position, as outlined in the previous paragraph; however, the evidence discussed in Section 3 does not support a strong 
reliance on the 'embodiment' effect.

Another interpretation of the hostile risk results is a short-termist one, and it could read as follows. An intensification in the threat of hostile takeover raises the manager's discount rate, and thus (inefficiently) leads to a fall in investment. The threat intensification also leads managers to issue dividends in a wasteful attempt to signal their quality to shareholders and the stock market. ${ }^{27}$ There is no improvement in corporate performance, as measured by productivity.

The short-termist explanation does indeed seem to be consistent with the results. An observer who attributed an important (positive) role for investment in TFP growth would object that if myopia is significant then we should expect to observe a negative effect of hostile risk on productivity after some lag. However, we observe no such effect. As already discussed, the investment-TFP growth nexus is an open question. However, it seems fair to say that the short-termism view would be more strongly supported if there were a negative effect of hostile risk on TFP.

Hence our evidence on the threat of hostile takeover appears to be partially consistent with both a Jensen view and a short-termist one. Neither view is strongly supported by the results, but both can explain some of the findings.

Now we turn to the probability of friendly takeover. At the outset we note that the analysis is hampered somewhat by the absence of any theory that predicts how the probability of a future friendly takeover affects current company performance. Of course there exist theories that explain how a consummated friendly takeover can affect performance (for example, via synergies). But no theory explains how the expectation of a future friendly bid affects current managerial behaviour. This is in contrast to the case of hostile takeovers, where the short-termist and disciplinary theories provide an explanation of how the expectation of a future bid affects current performance. Indeed given that a friendly takeover is defined as one that does not reduce a manager's rents, it is not clear whether or how we should expect friendly risk to alter current

\footnotetext{
${ }^{27}$ Nuttall $(1999 a, b)$ finds that dividend payout does not significantly reduce (hostile) takeover likelihood when other key variables (such as Tobin's Q and company age) are included in the model. This suggests that dividend signalling is not only wasteful, but futile.
} 
managerial behaviour. Therefore our discussion of the friendly results is necessarily rather speculative.

The robust effects of friendly risk on subsequent productivity (positively) and investment (negatively) are somewhat puzzling. The effects may to some extent reflect misclassification of bid types, if our classification scheme errs in the direction of classifying too few bids as hostile. In this case some of the 'friendly' effects would in fact reflect hostile effects. This explanation is certainly congenial to the Jensen view, but cannot provide a complete explanation because of the differences between the results for the hostile and friendly risk, particularly in the dividends model.

To conclude, therefore, our findings on the aggregate threat of takeover are consistent with a Jensen view of the market for corporate control. However, looking at the distinction between hostile and friendly effects raises problems with this story. The hostile risk effects are not inconsistent with a Jensen interpretation, though the interpretation would be more persuasive in the presence of a clear positive effect on productivity. The hostile takeover results are also consistent with a short-termism view, although this view would be more strongly supported if we observed a negative effect of takeover risk on productivity. The friendly takeover results are slightly puzzling, and the interpretation is hampered somewhat by the absence of any theory of how friendly risk should be expected to affect company performance. Given our classification scheme, we might expect that the friendly effects could reflect hostile intent to some extent. However, we have little indication of the importance of this effect, and given the observed differences between the effects of hostile and friendly risk this explanation cannot be a complete one.

\section{Conclusion}

This paper has undertaken an empirical analysis of the effects of the threat of takeover on company performance based on our panel of 643 UK companies over the period 1989-96. We use a two-stage approach in which predicted probabilities are generated from recursively-estimated takeover likelihood models, and then these probabilities are 
entered as regressors in models of productivity, investment and dividend payout.

Our main findings are as follows. The overall threat of takeover has a positive effect on subsequent productivity, a negative effect on subsequent investment, and a positive but insignificant effect on current dividend payout. When we distinguish between the probability of friendly and hostile takeover, we find that the lagged hostile risk has an effect on productivity that is statistically indistinguishable both from zero and from the friendly effect, which is positive. The hostile risk has a significant negative effect on twice-lagged investment, and a strongly positive effect on dividend payout. The probability of friendly takeover has a positive effect on subsequent productivity and a negative effect on subsequent investment. However, dividend payout is not significantly affected by friendly risk. Our findings are robust to including the key regressors from the takeover likelihood models as explanatory variables in the performance models.

In quantitative terms, our results imply that the long-run effect of an increase in the aggregate probability of takeover by $5 \%$ (which is roughly one standard deviation) is to raise total factor productivity by $7.0 \%$ and to reduce investment by $1.7 \%$. In addition, the long-run effect of an increase in the probability of hostile takeover by $3 \%$ (which again is roughly one standard deviation) is to raise the dividend-to-sales ratio by $2.3 \%$.

Together with Bond-Meghir-Windmeijer (1998), these findings provide the first quantitative measures of which we are aware of the effects of the threat of takeover-as distinct from the consummation of takeover-on company performance. Our findings are broadly consistent with two very different views on the operation of the market for corporate control. On the one hand the results are partially consistent with a Jensen (1986) story, whereby the threat of takeover reigns in managerial overinvestment, encourages managers to pay out greater dividends to commit to reduced non-value-maximizing behaviour (Zwiebel 1996), and thereby leads to productivity improvements. However, this explanation would be more strongly supported if there was a clear positive effect of the risk of hostile takeover on productivity. On the other hand the results are also partially consistent with a myopia view of the threat of takeover. 
On this view the threat of hostile takeover raises the managerial discount rate, thus reducing investment, and induces wasteful dividend signalling. The fact that hostile risk has no effect on productivity is only to be expected therefore, and indeed a negative effect (which is not observed) would have provided even more compelling evidence in favour of this view. In order to discriminate more clearly between the Jensen and short-termism views, it would be interesting to examine different sample periods. ${ }^{28}$

The results on the friendly risk provide something of a puzzle. To some extent they may reflect misclassification of hostile intent as friendly takeover. But this runs up against the objection that we observe different effects of the hostile and friendly risk in the investment and dividend models. The absence of any theory of how the risk of friendly takeover should be expected to affect managerial behaviour makes the analysis even less straightforward.

As we discussed in Section 5, however, our results could also be explained by endogenous attrition in our dataset. Formally, we should think of the current study as testing the joint null hypothesis that the probability of takeover has no effect on measures of performance and that the attrition process is exogenous for the performance equation.

In closing, we mention two avenues for future research that follow from the current analysis. First, it would be interesting to examine the externalities arising from takeover. When one firm is acquired, this presumably raises the probability that other firms in related industries will become the targets of takeover bids. To the extent that there is a disciplinary effect which leads to performance improvements, there is a positive externality from takeover. If, however, the threat of takeover has a primarily short-termist effect, then the externality is negative. These questions could in principle be examined using the methodology and data of the current paper.

Secondly, the methodology used in this paper could be used to study other deterrent effects present in the market for corporate control. For example, Denis-Denis-Sarin

\footnotetext{
${ }^{28}$ There is evidence that the ex post effects of takeover on company performance have varied across different time periods during the past twenty years. See Higson-Elliott (1998) for the UK and Mikkelson-Partch (1997) for the US.
} 
(1997b) have found that decreases in diversification are associated with external corporate control threats such as failed takeover bids and block share purchases. The threat effects on diversification could perhaps be examined with greater precision using the takeover likelihood measures in the present study. 


\section{Data Appendix}

Most of the accounting items were taken directly from Datastream, as described in the Data Appendix Table. Adjustments were made to obtain a consistent series for investment, and to estimate the net capital stock at replacement cost.

Our measure of investment records gross fixed investment. For the period up to and including 1991 we use ds435, which was Datastream's total new fixed assets variable, from the sources and uses accounts. This variable is the sum of ds431 (flow of expenditure on gross direct purchases of fixed assets) and ds432 (the book value of gross acquisitions of fixed assets). Following the change in UK accounting procedures in 1991, ds431 is relabelled ds1024 and ds432 is no longer available. In place of ds432 we use $\max [0, \mathrm{ds} 479]$, where ds479 is as ds432, except net of the book value of divestments of fixed assets.

Our capital stock variable $p_{t}^{K} K_{i t}$ is a replacement cost estimate of net fixed assets at current prices, where $p_{t}^{K}$ is an implicit price deflator for capital goods. We take the book value of net fixed assets (ds339) in the first sample year for a company, and adjust for pre-sample capital goods price inflation making the assumption that all capital is three years old. The ds339 variable comprises land, buildings, plant and machinery, and excludes inventories. For subsequent years we allow for depreciation and inflation according to the perpetual inventory formula

$$
p_{t+1}^{K} K_{i t+1}=\left[(1-\delta) p_{t}^{K} K_{i t}\right] \frac{p_{t+1}^{K}}{p_{t}^{K}}+p_{t+1}^{K} I_{i t+1}
$$

with $\delta=0.08$, where $p_{t}^{K} I_{i t}$ is gross fixed investment, as described above. I thank Steve Bond for providing the Fortran program that computes this formula.

The investment price series $p_{t}^{K}$ is formed using Office for National Statistics (ONS) data as the weighted sum of price series for buildings and for plant/machinery, where the weights reflect the respective shares in aggregate investment.

Our 2-digit SIC output price series, taken from ONS publications, was kindly provided by Daphne Nicolitsas. Firms were allocated to SIC groups based on their Stock Exchange sector classification. 
Our initial sample is a panel of 767 nonfinancial companies that were listed on the London Stock Exchange in December 1987, and that did not die before June 1988. Various 'cleaning' procedures were applied to the data. Companies with the following data characteristics were removed entirely from the dataset: companies with fewer than two observations; companies with missing series on key variables (such as sales revenue and employment); and companies with fewer than 50 employees. These procedures reduced the sample from an initial 767 companies to 687 companies. Our rumours data begin in 1988; this further reduces the sample from 687 to 643 companies.

Implausible employment observations were replaced by figures from Extel where possible. ${ }^{1}$ We also examined series with large jumps in the key production function variables, namely sales, employment and the capital stock. The standard approach is to exclude companies with large jumps (for example year-on-year changes of a factor exceeding three). Whilst this approach may be sensible for some empirical questions, it does not seem appropriate here because if two companies merge then we would fully expect sales, employment and capital to increase, possibly by a large amount. Thus we looked for jumps in ratios between the key variables, namely the ratios of salesto-labour, capital-to-sales, and capital-to-labour. The logarithms of these ratios are roughly symmetrically distributed, and a jump of a factor of three in the ratio itself corresponds approximately to a change in the logarithm of the ratio of at least five standard deviations from the mean. Sixty-six companies had changes of more than a factor of three in these ratios at some point during the sample period. In each case we assessed whether the jumps were implausible (for example with reference to reports in the Financial Times), and if so we excluded the appropriate series.

Observations on accounting year periods of less than 11 months or more than 13 months were removed. Only consecutive yearly observations were kept. If an accounting year in a company's series was either missing or relates to a financial year that is shorter than 11 months or longer than 13 months, then the observation was removed,

\footnotetext{
${ }^{1}$ We use Datastream rather than Extel as our primary source of accounting data because Extel generally removes dead companies soon after exit, while Datastream provides reasonably full coverage of dead firms (at least for our period of interest, namely 1989-96). For a study of takeovers, this is obviously a decisive factor in Datastream's favour.
} 
and the longer post-1988 series was kept. For example, suppose a company reports in accounting years 1988-95, but that the 1990 observation is either missing or relates to a non-12-month period. Then we removed the 1988-90 observations, but kept the 1991-95 series. Thus although all of our companies were listed on the London Stock Exchange in January 1988, the data series for some of our companies do not begin until after 1988. This explains the fact that in Column 1 of Table 1 there are only 579 companies with data for 1988, even though there were 687 companies in our sample.

Details of which firms were the subject of successful takeover bids were obtained from the London Share Price Database, which records company exits, death date, and reason for exits. However, for takeovers the LSPD death date refers to the listing cancellation, which often occurs several months after the actual bid is accepted by the target shareholders. Hence for each takeover exit we checked the Financial Times for the correct date of bid acceptance, and used this date as the death date.

The LSPD also provides a Stock Exchange sector classification variable. Scott Evans kindly provided an algorithm that maps this classification into a 2-digit SIC industry code. We used this algorithm to allocate each of our companies to a 2-digit SIC industry.

For the purposes of data analysis, it was necessary to create a 'year' variable for each observation. If a company's financial year ends between January and June, then this observation is classified as belonging to the previous calendar year; if a company's financial year ends between July and December, then this observation is classified as belonging to the current calendar year. For example, consider a company whose financial year ends in January. Then data from company accounts (for example, sales, employment, debt etc) for the 12 month period ending in January 1988 are classified as 1987 data by our 'year' variable. However, for a company whose financial year ends in December, data from company accounts that are reported in December 1988 are classified as 1988 by our 'year' variable.

Information on takeover speculation was taken from the Financial Times CD-ROM for 1988-95. ${ }^{2}$ For each company in the sample a search was performed for the keywords

\footnotetext{
${ }^{2}$ The Financial Times CD-ROM is not available for years before 1988 .
} 
'speculation', 'rumours' or 'bid talk', and was cross-referenced with various merger keywords such as 'takeover', 'bid' and 'acquisition'. Each hit resulting from this search was read, and a unit (date-specific) observation recorded for each article in which a company was touted as a potential takeover target. ${ }^{3}$ For the purpose of regression analysis, these date-specific observations were aggregated into a yearly count for each company. ${ }^{4}$ We found that grouping all observations where there were 3 or more rumours gave a slightly improved fit compared to using the raw rumour count variable, reflecting the fact that the distribution of the rumour count is very skewed (see Nuttall 1999a,b). Hence in the reported regression analysis we used a specification where values $0,1,2,3$ correspond to 0 rumours, 1 rumour, 2 rumours and 3 or more rumours respectively. However, all our results were robust to alternative specifications of the measure of rumours.

\footnotetext{
${ }^{3}$ We also distinguished 'serious' from 'less serious' speculation, where serious speculation names a bidder as well as the target; this distinction proved to be uninformative in the regression analysis.

${ }^{4}$ Consistent with the use of company accounts data in the study, this yearly count refers to the accounting year of each company, not the calendar year.
} 
Data Appendix Table: Description of Variables

\begin{tabular}{|c|c|c|c|}
\hline Variable & Symbol & Description & Source \\
\hline Sales Revenues & $Y$ & ds104 & Datastream \\
\hline Log Real Sales & $y$ & $\begin{array}{l}\text { ds104 deflated by a 2-digit SIC } \\
\text { output price series, in logs }\end{array}$ & $\begin{array}{l}\text { Datastream; Office for National } \\
\text { Statistics. }\end{array}$ \\
\hline Employment & $l$ & Log of ds 219 & $\begin{array}{l}\text { Datastream, replaced with } \\
\text { Extel data where appropriate. }\end{array}$ \\
\hline Capital stock & $K$ & $\begin{array}{l}\text { Replacement cost estimate of } \\
\text { the capital stock }\end{array}$ & $\begin{array}{l}\text { Datastream (see Data } \\
\text { Appendix) }\end{array}$ \\
\hline Real Capital Stock & $k$ & $\begin{array}{l}K \text { deflated by investment price } \\
\text { series, in logs }\end{array}$ & ONS \\
\hline Investment level & $I$ & Gross investment & $\begin{array}{l}\text { Datastream (see Data } \\
\text { Appendix) }\end{array}$ \\
\hline Investment rate & $I_{\mathrm{t}} / K_{\mathrm{t}-1}$ & & \\
\hline $\begin{array}{l}\text { Probability of firm } i \\
\text { being taken over in } \\
\text { year } t+1 \text {, given } \\
\text { information at year } t\end{array}$ & $p_{\text {it }}$ & $\begin{array}{l}\text { Predicted probability from } \\
\text { takeover likelihood model }\end{array}$ & See text \\
\hline Profits & $\pi$ & $\begin{array}{l}\text { Profits net of interest, taxes and } \\
\text { depreciation, gross of dividends } \\
\text { (ds182) }\end{array}$ & Datastream \\
\hline Return-on-sales & $\pi / Y$ & & \\
\hline Return-on-capital & $\pi / K$ & & \\
\hline Cash flow & $C$ & $\begin{array}{l}\text { Profits net of interest and taxes } \\
\text { plus depreciation (ds182+ds136) }\end{array}$ & Datastream \\
\hline $\begin{array}{l}\text { Cash flow return-on- } \\
\text { sales }\end{array}$ & $C / Y$ & & \\
\hline Dividend level & $D$ & ds187 & Datastream \\
\hline Dividends-to-sales & $D / Y$ & & \\
\hline Leverage & $L E V$ & Debt-Capital Ratio (ds321/K) & $\begin{array}{l}\text { Datastream. } \\
\text { Debt is book value. }\end{array}$ \\
\hline Tobin's Q & $Q$ & $(\mathrm{ds} 321+\mathrm{HMV}) / \mathrm{K}$ & $\begin{array}{l}\text { Datastream. } \\
\text { HMV is market valuation of } \\
\text { equity on the last day of the } \\
\text { accounting year. }\end{array}$ \\
\hline Income gearing & $F F P$ & $\begin{array}{l}\text { Interest payments relative to } \\
\text { earnings } \\
(\mathrm{ds} 153 /(\mathrm{ds} 153+\mathrm{ds} 157+\mathrm{ds} 136))\end{array}$ & Datastream \\
\hline Age & & $\begin{array}{l}\text { Measured in years from listing } \\
\text { on London Stock Exchange }\end{array}$ & London Share Price Database. \\
\hline Liquidity & & $\begin{array}{l}\text { Total cash and equivalent } \\
\text { deflated by the capital stock } \\
(\text { ds } 375 / K)\end{array}$ & Datastream. \\
\hline Rumours & Rum & $\begin{array}{l}\text { Annual count of number of } \\
\text { articles reporting takeover } \\
\text { speculation on the company in } \\
\text { question; see Data Appendix. }\end{array}$ & $\begin{array}{l}\text { Financial Times CD-ROM } \\
\text { 1988-95. }\end{array}$ \\
\hline GDP & & GDP volume index & OECD \\
\hline
\end{tabular}


Tables

Table 1: Sample Incidence of Corporate Control Events

\begin{tabular}{|c|c|c|c|c|c|c|c|}
\hline Year & $\begin{array}{c}\text { Number } \\
\text { of } \\
\text { companies }\end{array}$ & $\begin{array}{c}\text { Friendly } \\
\text { takeovers }\end{array}$ & $\begin{array}{c}\text { Failed } \\
\text { friendly } \\
\text { bids }\end{array}$ & $\begin{array}{c}\text { Hostile } \\
\text { takeovers }\end{array}$ & $\begin{array}{c}\text { Failed } \\
\text { hostile } \\
\text { bids }\end{array}$ & $\begin{array}{c}\text { Bid targets } \\
\text { overall }\end{array}$ & Bankruptcies \\
\hline 1988 & 579 & 26 & 0 & 13 & 5 & 44 & 2 \\
\hline 1989 & 550 & 26 & 1 & 10 & 6 & 43 & 10 \\
\hline 1990 & 526 & 21 & 3 & 7 & 3 & 34 & 11 \\
\hline 1991 & 508 & 19 & 0 & 2 & 3 & 24 & 8 \\
\hline 1992 & 495 & 7 & 0 & 3 & 3 & 13 & 6 \\
\hline 1993 & 483 & 6 & 1 & 0 & 0 & 7 & 1 \\
\hline 1994 & 462 & 6 & 0 & 2 & 2 & 10 & 3 \\
\hline 1995 & 438 & 12 & 0 & 6 & 1 & 19 & 1 \\
\hline 1996 & 59 & 6 & 0 & 1 & 0 & 7 & 0 \\
\hline Totals & & 129 & 5 & 44 & 23 & 201 & 42 \\
\hline
\end{tabular}

Notes:

1. Observations on accounting years are allocated to the current calendar year if the accounting year ends in July-December, and to the preceding calendar year if the accounting year ends in January-June. See also the Data Appendix for a description of the 'year' variable.

2. At time of sampling, only 59 companies had company accounts reported by Datastream for 1996. 
Table 2: Takeover likelihood model: Friendly versus Hostile Targets

Marginal effects from multinomial logit regression.

Sample period is 1989-96.

Number of observations $=4100$.

$\chi^{2}(26)=146.6 ;$ P-Value $=0.0000$. Log Likelihood $=-669.1$

Likelihood Ratio Index $=0.1186$

\begin{tabular}{|l|r|r|r|r|r|r|}
\hline & \multicolumn{3}{|c|}{ Friendly Targets } & \multicolumn{3}{c|}{ Hostile Targets } \\
\hline \multicolumn{1}{|c|}{$\begin{array}{c}\text { Marginal } \\
\text { effect }\end{array}$} & $\begin{array}{c}\text { Standard } \\
\text { error }\end{array}$ & P-Value & $\begin{array}{c}\text { Marginal } \\
\text { effect }\end{array}$ & $\begin{array}{c}\text { Standard } \\
\text { error }\end{array}$ & P-Value \\
\hline Log Real Capital Stock & -.0024 & .0012 & 0.049 & .00051 & .00054 & 0.34 \\
\hline Return-on-Sales & -.0312 & .0233 & 0.18 & -.0099 & .0122 & 0.41 \\
\hline Q & -.0020 & .00081 & 0.01 & -.0017 & .00062 & 0.006 \\
\hline Sectoral Q & .0015 & .0013 & 0.25 & .00020 & .00072 & 0.77 \\
\hline Leverage & .0055 & .0028 & 0.05 & -.0012 & .0036 & 0.73 \\
\hline Sectoral Leverage & -.0096 & .0130 & 0.46 & .0038 & .0059 & 0.52 \\
\hline Income Gearing & .00025 & .00094 & 0.78 & .000015 & .000036 & 0.67 \\
\hline Sectoral Income Gearing & .00032 & .00095 & 0.73 & -.00010 & .000048 & 0.03 \\
\hline Takeover Rumours & .0074 & .0029 & 0.01 & .0043 & .0012 & 0.00 \\
\hline Age 1-5 Years Dummy & .0530 & .0080 & 0.00 & .0094 & .0048 & 0.05 \\
\hline Age 6-9 Years Dummy & .0238 & .0047 & 0.00 & -.0075 & .0057 & 0.19 \\
\hline Aggregate Takeover & .00020 & .000071 & 0.004 & .000069 & .000035 & 0.05 \\
Activity & & & & & & \\
\hline Real GDP Growth & .0013 & .00083 & 0.10 & .001163 & .0004459 & 0.009 \\
\hline
\end{tabular}

Notes:

1. Time dummies are excluded.

2. Industry dummies are insignificant and thus excluded.

3. Regressors scaled so that means lie on the unit interval. Marginal effects evaluated at means of variables.

4. $\chi^{2}$ statistic is for a Wald test of the null hypothesis that the marginal effects are jointly insignificantly different from zero.

5. The Likelihood Ratio Index — which is also known as McFadden's (pseudo) R-squaredhas been recommended by Cameron-Windmeijer (1997) as a measure of goodness-of-fit for the logit model. 
Table 3: Summary Statistics on Actual Sample Frequency and Predicted Probabilities

Sample period 1989-96. 4100 observations.

\begin{tabular}{|l|r|r|}
\hline \multicolumn{1}{|c|}{ Probability } & \multicolumn{1}{c|}{ Mean } & Std. Dev. \\
\hline & & \\
\hline Sample Frequency of All-target takeover bids & .0380 & .1913 \\
\hline Recursive All-target Predicted Probabilities & .0391 & .0544 \\
\hline & & \\
\hline Sample Frequency of Friendly-target takeover bids & .0263 & .1601 \\
\hline Recursive Friendly-target Predicted Probabilities & .0260 & .0399 \\
\hline & & \\
\hline Sample Frequency of Hostile-target takeover bids & .0117 & .1075 \\
\hline Recursive Hostile-target Predicted Probabilities & .0130 & .0290 \\
\hline
\end{tabular}


Table 4: Prediction Tables. Recursive Model. Hostile targets.

Table 4.1: Hostile-target predicted probabilities for 1989

\begin{tabular}{|c|c|c|c|}
\hline & \multicolumn{3}{|c|}{ Actual Bids in Subsequent Year } \\
\hline Probability-Ranked Observations & Top & Bottom & Top/Bottom \\
\hline 10 & 3 & 0 & \\
\hline 20 & 6 & 0 & \\
\hline 30 & 7 & 0 & \\
\hline 40 & 7 & 0 & \\
\hline 50 & 7 & 0 & \\
\hline 100 & 9 & 0 & \\
\hline 200 & 12 & 0 & \\
\hline 290 & 14 & 2 & 7 \\
\hline
\end{tabular}

Total Number of observations: $\quad 579$

Total number of hostile bids: $\quad 16$

Table 4.2: Hostile predicted probabilities year-by-year

\begin{tabular}{|c|c|c|c|c|c|}
\hline $\begin{array}{c}\text { Year } \\
\text { of bid }\end{array}$ & $\begin{array}{c}\text { Number of } \\
\text { observations } \\
\text { in preceding } \\
\text { year }\end{array}$ & $\begin{array}{c}\text { Number of } \\
\text { actual bids }\end{array}$ & $\begin{array}{c}\text { Number of } \\
\text { bids in top } \\
\text { half of ranked } \\
\text { observations }\end{array}$ & $\begin{array}{c}\text { Number of } \\
\text { bids in bottom } \\
\text { half of ranked } \\
\text { observations }\end{array}$ & Top/bottom \\
\hline 1989 & 579 & 16 & 14 & 2 & 7 \\
\hline 1990 & 550 & 10 & 8 & 2 & 4 \\
\hline 1991 & 526 & 5 & 5 & 0 & - \\
\hline 1992 & 508 & 6 & 4 & 2 & 2 \\
\hline 1993 & 495 & 0 & 0 & 0 & - \\
\hline 1994 & 483 & 4 & 2 & 2 & 1 \\
\hline 1995 & 462 & 7 & 6 & 1 & 6 \\
\hline 1996 & 438 & 1 & 0 & 1 & 0 \\
\hline
\end{tabular}




\section{Table 5: Production Function Model}

Dependent variable is $y_{\text {it }}$ ( $\log$ real sales).

Sample period is 1989 to 1996.

551 companies; 3413 observations.

\begin{tabular}{|c|c|c|c|c|c|}
\hline $\begin{array}{l}\text { Independent } \\
\text { Variable }\end{array}$ & Col. (1) & Col. (2) & Col. (3) & Col. (4) & Col. (5) \\
\hline$y_{\mathrm{it}-1}$ & $\begin{array}{l}0.5993 \\
(0.1042)^{\mathrm{a}}\end{array}$ & $\begin{array}{l}0.7935 \\
(0.0536)^{\mathrm{a}}\end{array}$ & $\begin{array}{l}0.6716 \\
(0.0766)^{\mathrm{a}}\end{array}$ & $\begin{array}{l}0.8656 \\
(0.0487)^{\mathrm{a}}\end{array}$ & $\begin{array}{l}0.6630 \\
(0.0798)^{\mathrm{a}}\end{array}$ \\
\hline$l_{\text {it }}$ & $\begin{array}{l}0.7429 \\
(0.1044)^{\mathrm{a}}\end{array}$ & $\begin{array}{l}0.7675 \\
(0.0816)^{\mathrm{a}}\end{array}$ & $\begin{array}{l}0.7236 \\
(0.1009)^{\mathrm{a}}\end{array}$ & $\begin{array}{l}0.7555 \\
(0.0929)^{\mathrm{a}}\end{array}$ & $\begin{array}{l}0.7654 \\
(0.0919)^{\mathrm{a}}\end{array}$ \\
\hline$l_{\text {it-1 }}$ & $\begin{array}{l}-0.5723 \\
(0.1147)^{\mathrm{a}}\end{array}$ & $\begin{array}{l}-0.6066 \\
(0.0846)^{\mathrm{a}}\end{array}$ & $\begin{array}{l}-0.5540 \\
(0.1192)^{\mathrm{a}}\end{array}$ & $\begin{array}{l}-0.6409 \\
(0.1028)^{\mathrm{a}}\end{array}$ & $\begin{array}{l}-0.5811 \\
(0.1056)^{\mathrm{a}}\end{array}$ \\
\hline$k_{\mathrm{it}}$ & $\begin{array}{l}0.3495 \\
(0.1344)^{\mathrm{a}}\end{array}$ & $\begin{array}{l}0.1793 \\
(0.1078)^{c}\end{array}$ & $\begin{array}{l}0.3241 \\
(0.1301)^{\mathrm{b}}\end{array}$ & $\begin{array}{l}0.1588 \\
(0.1210)\end{array}$ & $\begin{array}{l}0.2635 \\
(0.1191)^{b}\end{array}$ \\
\hline$k_{\text {it-1 }}$ & $\begin{array}{l}-0.2233 \\
(0.1252)^{\mathrm{c}}\end{array}$ & $\begin{array}{l}-0.1397 \\
(0.1014)\end{array}$ & $\begin{array}{l}-0.2096 \\
(0.1204)^{\mathrm{c}}\end{array}$ & $\begin{array}{l}-0.1409 \\
(0.1099)\end{array}$ & $\begin{array}{l}-0.1792 \\
(0.1145)^{\mathrm{c}}\end{array}$ \\
\hline$p^{F_{i t-1}}$ & & $\begin{array}{l}0.9275 \\
(0.4674)^{\mathrm{b}}\end{array}$ & & $\begin{array}{l}0.7519 \\
(0.4779)\end{array}$ & \\
\hline$p^{\mathrm{H}}{ }_{\mathrm{it}-1}$ & & & $\begin{array}{l}0.1369 \\
(0.2436)\end{array}$ & $\begin{array}{l}-0.0858 \\
(0.2723)\end{array}$ & \\
\hline$p^{\mathrm{A}}{ }_{\mathrm{it}-1}$ & & & & & $\begin{array}{l}0.4747 \\
(0.2108)^{b}\end{array}$ \\
\hline $\mathrm{m} 1$ & 0.00 & 0.00 & 0.00 & 0.00 & 0.00 \\
\hline $\mathrm{m} 2$ & 0.86 & 0.53 & 0.73 & 0.48 & 0.78 \\
\hline Sargan & 0.81 & 0.17 & 0.54 & 0.09 & 0.58 \\
\hline
\end{tabular}

Notes:

1. Time dummies are included in all specifications. Industry dummies (in the levels equations) are insignificant and thus excluded.

2. Predicted probabilities generated by a recursively-estimated takeover likelihood model.

3. All equations estimated with one-step GMM system estimator. Instruments for equations in first-differences are $y_{\mathrm{it}-2}, l_{\mathrm{it}-2}, k_{\mathrm{it}-2}, p_{\mathrm{it}-2}$ and further lags. Instruments for equations in levels are $\Delta l_{\mathrm{it}-1}, \Delta k_{\mathrm{it}-1}$ and $\Delta \mathrm{p}_{\mathrm{it}-1}$. Instruments $\Delta \mathrm{y}_{\mathrm{it}-1}$ are rejected by Sargan test, and thus excluded.

4. In parentheses are asymptotic standard errors robust to general cross-section and timeseries heteroskedasticity. The superscript ' $a$ ' indicates that the coefficient is significantly different from zero at the 0.01 level, ' $b$ ' at the 0.05 level and ' $c$ ' at the 0.10 level.

5. $\mathrm{m} 1$ and $\mathrm{m} 2$ are test statistics, distributed standard normal, for first- and second-order serial correlation in the first-differenced residuals. Sargan statistic is that for the corresponding two-step GMM estimator, distributed chi-squared. P-values are reported. 


\section{Table 6: Production Function Model: Robustness}

Dependent variable is $y_{\text {it }}$ (log real sales).

Sample period is 1989 to 1996.

551 companies; 3413 observations.

\begin{tabular}{|c|c|c|c|c|c|}
\hline $\begin{array}{l}\text { Independent } \\
\text { Variable }\end{array}$ & Col. (1) & Col. (2) & Col. (3) & Col. (4) & Col. (5) \\
\hline$y_{\mathrm{it}-1}$ & $\begin{array}{l}0.6814 \\
(0.0744)^{\mathrm{a}}\end{array}$ & $\begin{array}{l}0.6395 \\
(0.0765)^{\mathrm{a}}\end{array}$ & $\begin{array}{l}0.7134 \\
(0.0669)^{\mathrm{a}}\end{array}$ & $\begin{array}{l}0.6319 \\
(0.0855)^{\mathrm{a}}\end{array}$ & $\begin{array}{l}0.8292 \\
(0.0594)^{\mathrm{a}}\end{array}$ \\
\hline$l_{\text {it }}$ & $\begin{array}{l}0.7879 \\
(0.0805)^{\mathrm{a}}\end{array}$ & $\begin{array}{l}0.7685 \\
(0.0888)^{\mathrm{a}}\end{array}$ & $\begin{array}{l}0.7671 \\
(0.0890)^{\mathrm{a}}\end{array}$ & $\begin{array}{l}0.7289 \\
(0.0959)^{\mathrm{a}}\end{array}$ & $\begin{array}{l}0.7779 \\
(0.0836)^{\mathrm{a}}\end{array}$ \\
\hline$l_{\text {it-1 }}$ & $\begin{array}{l}-0.5823 \\
(0.0965)^{\mathrm{a}}\end{array}$ & $\begin{array}{l}-0.5709 \\
(0.1025)^{\mathrm{a}}\end{array}$ & $\begin{array}{l}-0.5877 \\
(0.1082)^{\mathrm{a}}\end{array}$ & $\begin{array}{l}-0.5240 \\
(0.1088)^{\mathrm{a}}\end{array}$ & $\begin{array}{l}-0.6361 \\
(0.1021)^{\mathrm{a}}\end{array}$ \\
\hline$k_{\text {it }}$ & $\begin{array}{l}0.1521 \\
(0.1092)\end{array}$ & $\begin{array}{l}0.2624 \\
(0.1118)^{b}\end{array}$ & $\begin{array}{l}0.2384 \\
(0.1149)^{\mathrm{b}}\end{array}$ & $\begin{array}{l}0.2562 \\
(0.1187)^{b}\end{array}$ & $\begin{array}{l}0.0893 \\
(0.0894)\end{array}$ \\
\hline$k_{\mathrm{it}-1}$ & $\begin{array}{l}-0.0907 \\
(0.1161)\end{array}$ & $\begin{array}{l}-0.1691 \\
(0.1079) \\
\end{array}$ & $\begin{array}{l}-0.1538 \\
(0.1109) \\
\end{array}$ & $\begin{array}{l}-0.1584 \\
(0.1156)\end{array}$ & $\begin{array}{l}-0.0546 \\
(0.0911) \\
\end{array}$ \\
\hline$p^{\mathrm{A}}{ }_{\text {it-1 }}$ & $\begin{array}{l}0.3742 \\
(0.2119)^{\mathrm{c}}\end{array}$ & $\begin{array}{l}0.4618 \\
(0.2061)^{b}\end{array}$ & $\begin{array}{l}0.7212 \\
(0.2993)^{b}\end{array}$ & $\begin{array}{l}0.4140 \\
(0.2063)^{\mathrm{b}}\end{array}$ & $\begin{array}{l}0.5339 \\
(0.2775)^{\mathrm{b}}\end{array}$ \\
\hline $\mathrm{Q}_{\mathrm{it}-1}$ & $\begin{array}{l}-0.0017 \\
(0.0031)\end{array}$ & & & & $\begin{array}{l}0.000025 \\
(0.0037)\end{array}$ \\
\hline $\mathrm{LEV}_{\mathrm{it}-1}$ & & $\begin{array}{l}0.0246 \\
(0.0081)^{\mathrm{a}}\end{array}$ & & & $\begin{array}{l}0.0302 \\
(0.0104)^{\mathrm{a}}\end{array}$ \\
\hline Rum $_{\text {it-1 }}$ & & & $\begin{array}{l}-0.0209 \\
(0.0133)\end{array}$ & & $\begin{array}{l}-0.0164 \\
(0.0122)\end{array}$ \\
\hline $\operatorname{Age}_{i t-1}$ & & & & $\begin{array}{l}-0.0019 \\
(0.0019) \\
\end{array}$ & $\begin{array}{l}-0.0004 \\
(0.0012) \\
\end{array}$ \\
\hline $\mathrm{m} 1$ & 0.00 & 0.00 & 0.00 & 0.00 & 0.00 \\
\hline $\mathrm{m} 2$ & 0.65 & 0.76 & 0.72 & 0.70 & 0.46 \\
\hline Sargan & 0.61 & 0.61 & 0.50 & 0.59 & 0.23 \\
\hline
\end{tabular}

Notes:

1. Time dummies are included in all specifications. Industry dummies (in the levels equations) are insignificant and thus excluded.

2. Predicted probabilities taken from a recursively-estimated takeover likelihood model.

3. All equations estimated with one-step GMM system estimator. All independent variables except for age (which is treated as exogenous) are instrumented. Instruments for equations in first-differences are as in Table 4.1, with additional regressors instrumented with twiceand further-lags. Instruments for equations in levels are the lagged first-differences of the included independent variables, except for $\Delta \mathrm{y}_{\mathrm{it}-1}$ and $\Delta \mathrm{LEV}_{\mathrm{it}-1}$, both of which are rejected by the Sargan test.

4. In parentheses are asymptotic standard errors robust to general cross-section and timeseries heteroskedasticity. The superscript ' $a$ ' indicates that the coefficient is significantly different from zero at the 0.01 level, 'b' at the 0.05 level and 'c' at the 0.10 level.

5. $\mathrm{m} 1$ and $\mathrm{m} 2$ are test statistics, distributed standard normal, for first- and second-order serial correlation in the first-differenced residuals. Sargan statistic is that for the corresponding two-step GMM estimator, distributed chi-squared. P-values are reported. 


\section{Table 7: Investment Model}

Dependent variable is $I_{\mathrm{t}} / K_{\mathrm{it}-1}$ (Investment rate)

Sample period is 1990 to 1996

494 companies; 2697 observations.

\begin{tabular}{|c|c|c|c|c|}
\hline Independent Variable & Col. (1) & Col. (2) & Col. (3) & Col. (4) \\
\hline$I_{\mathrm{t}-1} / K_{\mathrm{it}-2}$ & $\begin{array}{l}-0.0482 \\
(0.0535)\end{array}$ & $\begin{array}{l}-0.0598 \\
(0.0492)\end{array}$ & $\begin{array}{l}-0.0487 \\
(0.0524)\end{array}$ & $\begin{array}{l}-0.0383 \\
(0.0489)\end{array}$ \\
\hline$\Delta y_{\text {it }}$ & $\begin{array}{l}0.1938 \\
(0.0476)^{\mathrm{a}}\end{array}$ & $\begin{array}{l}0.2338 \\
(0.0501)^{\mathrm{a}}\end{array}$ & $\begin{array}{l}0.1800 \\
(0.0412)^{\mathrm{a}}\end{array}$ & $\begin{array}{l}0.2210 \\
(0.0511)^{\mathrm{a}}\end{array}$ \\
\hline$\Delta y_{\mathrm{it}-1}$ & $\begin{array}{l}0.0894 \\
(0.0226)^{\mathrm{a}}\end{array}$ & $\begin{array}{l}0.0921 \\
(0.0247)^{\mathrm{a}}\end{array}$ & $\begin{array}{l}0.0945 \\
(0.0210)^{\mathrm{a}}\end{array}$ & $\begin{array}{l}0.0866 \\
(0.0247)^{\mathrm{a}}\end{array}$ \\
\hline$\left(k_{\mathrm{it}-2}-y_{\mathrm{it}-2}\right)$ & $\begin{array}{l}-0.0786 \\
(0.0205)^{\mathrm{a}}\end{array}$ & $\begin{array}{l}-0.0835 \\
(0.0193)^{\mathrm{a}}\end{array}$ & $\begin{array}{l}-0.0803 \\
(0.0205)^{\mathrm{a}}\end{array}$ & $\begin{array}{l}-0.0701 \\
(0.0175)^{\mathrm{a}}\end{array}$ \\
\hline$y_{\mathrm{it}-2}$ & $\begin{array}{l}0.0110 \\
(0.0062)^{\mathrm{c}}\end{array}$ & $\begin{array}{l}0.0293 \\
(0.0104)^{\mathrm{a}}\end{array}$ & $\begin{array}{l}0.0104 \\
(0.0062)^{\mathrm{c}}\end{array}$ & $\begin{array}{l}0.0321 \\
(0.0106)^{a}\end{array}$ \\
\hline$C_{\mathrm{t}-1} / K_{\mathrm{it}-2}$ & $\begin{array}{l}0.0175 \\
(0.0111)\end{array}$ & $\begin{array}{l}0.0231 \\
(0.0122)^{\mathrm{c}}\end{array}$ & $\begin{array}{l}0.0150 \\
(0.0105)\end{array}$ & $\begin{array}{l}0.0219 \\
(0.0122)^{c}\end{array}$ \\
\hline$p_{\text {it-1 }}^{\mathrm{F}_{2}}$ & $\begin{array}{l}-0.9586 \\
(0.2950)^{\mathrm{a}}\end{array}$ & & $\begin{array}{l}-1.0569 \\
(0.3313)^{\mathrm{a}}\end{array}$ & \\
\hline$p^{\mathrm{H}}{ }_{\mathrm{it}-2}$ & & $\begin{array}{l}-0.2045 \\
(0.1137)^{\mathrm{c}}\end{array}$ & $\begin{array}{l}-0.3019 \\
(0.1278)^{b}\end{array}$ & \\
\hline$p^{\mathrm{A}}{ }_{\mathrm{it}-1}$ & & & & $\begin{array}{l}-0.2340 \\
(0.1239)^{b}\end{array}$ \\
\hline$p^{\mathrm{A}}{ }_{\mathrm{it}-2}$ & & & & $\begin{array}{l}-0.1275 \\
(0.0905)\end{array}$ \\
\hline Wald on probabilities & & & 0.003 & 0.14 \\
\hline $\mathrm{m} 1$ & 0.00 & 0.00 & 0.00 & 0.00 \\
\hline $\mathrm{m} 2$ & 0.30 & 0.47 & 0.25 & 0.00 \\
\hline Sargan & 0.15 & 0.10 & 0.13 & 0.21 \\
\hline
\end{tabular}

Notes:

1. Time dummies are included in all specifications. Industry dummies (in the levels equations) are insignificant and thus excluded.

2. Predicted probabilities taken from a recursively-estimated takeover likelihood model.

3. All equations estimated with one-step GMM system estimator. Instruments for equations in first differences are $\left(I_{\mathrm{t}-2} / K_{\mathrm{it}-3}\right),\left(k_{\mathrm{it}-2}-y_{\mathrm{it}-2}\right), y_{\mathrm{it}-2}, C_{\mathrm{t}-2} / K_{\mathrm{it}-3}, p_{\mathrm{it}-2}$ and further lags. Instruments for equations in levels are $\Delta\left(I_{\mathrm{t}-1} / K_{\mathrm{it}-2}\right), \Delta y_{\mathrm{it}-1}$ and $\Delta p_{\mathrm{it}-1}$.

4. In parentheses are asymptotic standard errors robust to general cross-section and timeseries heteroskedasticity. The superscript ' $a$ ' indicates that the coefficient is significantly different from zero at the 0.01 level, ' $b$ ' at the 0.05 level and ' $c$ ' at the 0.10 level.

5. Wald test applies if there are two probabilities included in the model, and is for the null hypothesis that the probabilities are jointly insignificantly different from zero. P-values are reported.

6. $\mathrm{m} 1$ and $\mathrm{m} 2$ are test statistics, distributed standard normal, for first- and second-order serial correlation in the first-differenced residuals. Sargan statistic is that for the corresponding two-step GMM estimator, distributed chi-squared. P-values are reported. 
Dependent variable is $I_{\mathrm{t}} / K_{\mathrm{it}-1}$ (Investment rate)

Sample period is 1990 to 1996

494 companies; 2697 observations.

\begin{tabular}{|c|c|c|c|c|c|}
\hline Independent Variable & Col. (1) & Col. (2) & Col. (3) & Col. (4) & Col. (5) \\
\hline$I_{\mathrm{t}-1} / K_{\mathrm{it}-2}$ & $\begin{array}{l}-0.0297 \\
(0.0503) \\
\end{array}$ & $\begin{array}{l}-0.0745 \\
(0.0530)\end{array}$ & $\begin{array}{l}-0.0607 \\
(0.0528)\end{array}$ & $\begin{array}{l}-0.0556 \\
(0.0559) \\
\end{array}$ & $\begin{array}{l}-0.0195 \\
(0.0476)\end{array}$ \\
\hline$\Delta y_{\text {it }}$ & $\begin{array}{l}0.1577 \\
(0.0373)^{\mathrm{a}}\end{array}$ & $\begin{array}{l}0.1891 \\
(0.0399)^{\mathrm{a}}\end{array}$ & $\begin{array}{l}0.1891 \\
(0.0389)^{\mathrm{a}}\end{array}$ & $\begin{array}{l}0.1799 \\
(0.0412)^{\mathrm{a}}\end{array}$ & $\begin{array}{l}0.1735 \\
(0.0345)^{\mathrm{a}}\end{array}$ \\
\hline$\Delta y_{\mathrm{it}-1}$ & $\begin{array}{l}0.0842 \\
(0.0207)^{\mathrm{a}}\end{array}$ & $\begin{array}{l}0.1051 \\
(0.0219)^{\mathrm{a}}\end{array}$ & $\begin{array}{l}0.0950 \\
(0.0211)^{\mathrm{a}}\end{array}$ & $\begin{array}{l}0.0998 \\
(0.0251)^{\mathrm{a}}\end{array}$ & $\begin{array}{l}0.0729 \\
(0.0199)^{\mathrm{a}}\end{array}$ \\
\hline$\left(k_{\mathrm{it}-2}-y_{\mathrm{it}-2}\right)$ & $\begin{array}{l}-0.0687 \\
(0.0201)^{\mathrm{a}}\end{array}$ & $\begin{array}{l}-0.0923 \\
(0.0220)^{\mathrm{a}}\end{array}$ & $\begin{array}{l}-0.0855 \\
(0.0213)^{\mathrm{a}}\end{array}$ & $\begin{array}{l}-0.0841 \\
(0.0233)^{\mathrm{a}}\end{array}$ & $\begin{array}{l}-0.0555 \\
(0.0179)^{\mathrm{a}}\end{array}$ \\
\hline$y_{\mathrm{it}-2}$ & $\begin{array}{l}0.0092 \\
(0.0064) \\
\end{array}$ & $\begin{array}{l}0.0116 \\
(0.0065)^{\mathrm{c}}\end{array}$ & $\begin{array}{l}0.0088 \\
(0.0062)\end{array}$ & $\begin{array}{l}0.0096 \\
(0.0063)\end{array}$ & $\begin{array}{l}0.0087 \\
(0.0039)^{\mathrm{b}}\end{array}$ \\
\hline$C_{\mathrm{t}-1} / K_{\mathrm{it}-2}$ & $\begin{array}{l}0.0026 \\
(0.0075)\end{array}$ & $\begin{array}{l}0.0032 \\
(0.0090)\end{array}$ & $\begin{array}{l}0.0148 \\
(0.0106)\end{array}$ & $\begin{array}{l}0.0146 \\
(0.0105)\end{array}$ & $\begin{array}{l}0.0030 \\
(0.0091)\end{array}$ \\
\hline$p^{\mathrm{F}}{ }_{\mathrm{it}-1}$ & $\begin{array}{l}-0.8126 \\
(0.2799)^{\mathrm{a}} \\
\end{array}$ & $\begin{array}{l}-1.0974 \\
(0.3481)^{\mathrm{a}}\end{array}$ & $\begin{array}{l}-1.1867 \\
(0.4141)^{\mathrm{a}}\end{array}$ & $\begin{array}{l}-1.0252 \\
(0.3119)^{\mathrm{a}}\end{array}$ & $\begin{array}{l}-0.7602 \\
(0.3398)^{b}\end{array}$ \\
\hline$p^{\mathrm{H}}{ }_{\mathrm{it}-2}$ & $\begin{array}{l}-0.3034 \\
(0.1237)^{b}\end{array}$ & $\begin{array}{l}-0.3018 \\
(0.1259)^{b}\end{array}$ & $\begin{array}{l}-0.2591 \\
(0.1286)^{b}\end{array}$ & $\begin{array}{l}-0.3011 \\
(0.1276)^{b}\end{array}$ & $\begin{array}{l}-0.2818 \\
(0.1170)^{b}\end{array}$ \\
\hline $\mathrm{Q}_{\mathrm{it}-1}$ & $\begin{array}{l}0.0052 \\
(0.0021)^{\mathrm{b}}\end{array}$ & & & & $\begin{array}{l}0.0031 \\
(0.0022) \\
\end{array}$ \\
\hline $\mathrm{Q}_{\mathrm{it}-2}$ & $\begin{array}{l}-0.0013 \\
(0.0010) \\
\end{array}$ & & & & $\begin{array}{l}-0.0009 \\
(0.0015) \\
\end{array}$ \\
\hline $\mathrm{LEV}_{\text {it- } 1}$ & & $\begin{array}{l}0.0031 \\
(0.0047)\end{array}$ & & & $\begin{array}{l}-0.0042 \\
(0.0067)\end{array}$ \\
\hline $\mathrm{LEV}_{\mathrm{it}-2}$ & & $\begin{array}{l}-0.0054 \\
(0.0045)\end{array}$ & & & $\begin{array}{l}-0.0032 \\
(0.0056)\end{array}$ \\
\hline Rum $_{\text {it-1 }}$ & & & $\begin{array}{l}0.0095 \\
(0.0063)\end{array}$ & & $\begin{array}{l}0.0091 \\
(0.0053)^{\mathrm{c}}\end{array}$ \\
\hline $\operatorname{Rum}_{\mathrm{it}-2}$ & & & $\begin{array}{l}0.0009 \\
(0.0039)\end{array}$ & & $\begin{array}{l}0.0038 \\
(0.0038) \\
\end{array}$ \\
\hline $\operatorname{Age}_{\mathrm{it}-1}$ & & & & $\begin{array}{l}0.0004 \\
(0.0006)\end{array}$ & $\begin{array}{l}-0.0003 \\
(0.0004)\end{array}$ \\
\hline Wald on $p^{\mathrm{F}}{ }_{\text {it- } 1}$ and $p^{\mathrm{H}}$ it-2 & 0.005 & 0.004 & 0.01 & 0.003 & 0.01 \\
\hline $\mathrm{m} 1$ & 0.00 & 0.00 & 0.00 & 0.00 & 0.00 \\
\hline $\mathrm{m} 2$ & 0.30 & 0.20 & 0.25 & 0.23 & 0.23 \\
\hline Sargan & 0.17 & 0.12 & 0.08 & 0.13 & 0.02 \\
\hline
\end{tabular}

Notes:

1. Time dummies are included in all specifications. Industry dummies (in the levels equations) are insignificant and thus excluded.

2. Predicted probabilities taken from a recursively-estimated takeover likelihood model.

3. All equations estimated with one-step GMM system estimator. All independent variables except for age (which is treated as exogenous) are instrumented. Instruments for equations 
in first-differences are as in Table 4.3, with additional regressors instrumented with twiceand further-lags. Instruments for equations in levels are as in Table 4.3; the Sargan test rejects $\Delta \mathrm{Q}_{\mathrm{it}-1}, \Delta \mathrm{LEV}_{\mathrm{it}-1}$ and $\Delta \mathrm{Rum}_{\mathrm{it}-1}$.

4. In parentheses are asymptotic standard errors robust to general cross-section and timeseries heteroskedasticity. The superscript ' $a$ ' indicates that the coefficient is significantly different from zero at the 0.01 level, ' $b$ ' at the 0.05 level and 'c' at the 0.10 level.

5. Wald test is for the null hypothesis $p^{\mathrm{F}}{ }_{\text {it- } 1}$ and $p^{\mathrm{H}}{ }_{\text {it-2 }}$ are jointly insignificantly different from zero. P-values are reported.

6. $\mathrm{m} 1$ and $\mathrm{m} 2$ are test statistics, distributed standard normal, for first- and second-order serial correlation in the first-differenced residuals. Sargan statistic is that for the corresponding two-step GMM estimator, distributed chi-squared. P-values are reported. 


\section{Table 9: Dividend Model}

Dependent variable is $(D / Y)_{\text {it }}$ (Dividend-to-sales ratio)

Sample period is 1990 to 1996

510 companies; 2821 observations.

\begin{tabular}{|c|c|c|c|c|c|}
\hline Independent Variable & Col. (1) & Col. (2) & Col. (3) & Col. (4) & Col. (5) \\
\hline$(D / Y)_{\mathrm{it}-1}$ & $\begin{array}{l}0.3063 \\
(0.1753)^{\mathrm{c}}\end{array}$ & $\begin{array}{l}0.2990 \\
(0.1778)^{\mathrm{c}}\end{array}$ & $\begin{array}{l}0.3236 \\
(0.1723)^{\mathrm{c}}\end{array}$ & $\begin{array}{l}0.2962 \\
(0.1645)^{\mathrm{c}}\end{array}$ & $\begin{array}{l}0.3076 \\
(0.1507)^{b}\end{array}$ \\
\hline$(\pi / Y)_{\text {it }}$ & $\begin{array}{l}0.0685 \\
(0.0259)^{\mathrm{a}}\end{array}$ & $\begin{array}{l}0.0651 \\
(0.0264)^{\mathrm{a}}\end{array}$ & $\begin{array}{l}0.0833 \\
(0.0253)^{\mathrm{a}}\end{array}$ & $\begin{array}{l}0.0581 \\
(0.0300)^{\mathrm{b}}\end{array}$ & $\begin{array}{l}0.0714 \\
(0.0315)^{b}\end{array}$ \\
\hline $\mathrm{Age}_{\mathrm{it}}$ & $\begin{array}{l}0.00064 \\
(0.00026)^{b}\end{array}$ & $\begin{array}{l}0.00068 \\
(0.00028)^{b}\end{array}$ & $\begin{array}{l}0.00046 \\
(0.00021)^{b}\end{array}$ & $\begin{array}{l}0.00056 \\
(0.00024)^{b}\end{array}$ & $\begin{array}{l}0.00041 \\
(0.00017)^{b}\end{array}$ \\
\hline$p^{\mathrm{A}_{\text {it }}}$ & $\begin{array}{l}0.2168 \\
(0.1484)\end{array}$ & $\begin{array}{l}0.1110 \\
(0.1164)\end{array}$ & & & \\
\hline$\overline{p^{\mathrm{A}}{ }_{\mathrm{it}-1}}$ & $\begin{array}{l}-0.0289 \\
(0.0236)\end{array}$ & & & & \\
\hline$p^{\mathrm{H}}{ }_{\text {it }}$ & & & $\begin{array}{l}0.5252 \\
(0.2128)^{\mathrm{a}}\end{array}$ & & $\begin{array}{l}0.3270 \\
(0.1874)^{c}\end{array}$ \\
\hline$p_{\text {it-1 }}^{\mathrm{F}}$ & & & & $\begin{array}{l}-0.0720 \\
(0.0462)\end{array}$ & $\begin{array}{l}-0.0519 \\
(0.0396)\end{array}$ \\
\hline Wald on probabilities & 0.31 & & & & 0.07 \\
\hline $\mathrm{m} 1$ & 0.04 & 0.04 & 0.01 & 0.04 & 0.02 \\
\hline $\mathrm{m} 2$ & 0.17 & 0.13 & 0.12 & 0.20 & 0.12 \\
\hline Sargan & 0.52 & 0.51 & 0.58 & 0.39 & 0.39 \\
\hline
\end{tabular}

Notes:

1. Time dummies are included in all specifications. Industry dummies (in the levels equations) are insignificant and thus excluded.

2. Predicted probabilities taken from a recursively-estimated takeover likelihood model.

3. All equations estimated with one-step GMM system estimator. Instruments for equations in first differences are $(D / Y)_{\mathrm{it}-2},(\pi / Y)_{\mathrm{it}-2}, p_{\mathrm{it}-2}$ and further lags; age is treated as exogenous. Instruments for equations in levels are $\Delta(\pi / Y)_{\mathrm{it}-1}$ and $\Delta p_{\mathrm{it}-1}$. Sargan test rejects $\Delta(D / Y)_{\mathrm{it}-1}$.

4. In parentheses are asymptotic standard errors robust to general cross-section and timeseries heteroskedasticity. The superscript ' $a$ ' indicates that the coefficient is significantly different from zero at the 0.01 level, 'b' at the 0.05 level and 'c' at the 0.10 level.

7. Wald test applies if there are two probabilities included in the model, and is for the null hypothesis that the probabilities are jointly insignificantly different from zero. P-values are reported.

5. $\mathrm{m} 1$ and $\mathrm{m} 2$ are test statistics, distributed standard normal, for first- and second-order serial correlation in the first-differenced residuals. Sargan statistic is that for the corresponding two-step GMM estimator, distributed chi-squared. P-values are reported. 


\section{Table 10: Dividend Model: Robustness}

Dependent variable is $(D / Y)_{\text {it }}$ (Dividend-to-sales ratio)

Sample period is 1990 to 1996

510 companies; 2821 observations.

\begin{tabular}{|c|c|c|c|c|}
\hline Independent Variable & Col. (1) & Col. (2) & Col. (3) & Col. (4) \\
\hline$(D / Y)_{\mathrm{it}-1}$ & $\begin{array}{l}0.2651 \\
(0.1468)^{\mathrm{c}}\end{array}$ & $\begin{array}{l}0.3271 \\
(0.1601)^{b}\end{array}$ & $\begin{array}{l}0.3943 \\
(0.1651)^{b}\end{array}$ & $\begin{array}{l}0.3284 \\
(0.1307)^{\mathrm{a}}\end{array}$ \\
\hline$(\pi / Y)_{\mathrm{it}}$ & $\begin{array}{l}0.0821 \\
(0.0244)^{\mathrm{a}}\end{array}$ & $\begin{array}{l}0.0758 \\
(0.0230)^{\mathrm{a}}\end{array}$ & $\begin{array}{l}0.0712 \\
(0.0182)^{\mathrm{a}}\end{array}$ & $\begin{array}{l}0.0656 \\
(0.0164)^{\mathrm{a}}\end{array}$ \\
\hline $\mathrm{Age}_{i t}$ & $\begin{array}{l}0.00051 \\
(0.00021)^{b}\end{array}$ & $\begin{array}{l}0.00046 \\
(0.00020)^{b}\end{array}$ & $\begin{array}{l}0.00022 \\
(0.00011)^{b}\end{array}$ & $\begin{array}{l}0.00024 \\
(0.00011)^{b}\end{array}$ \\
\hline$p^{\mathrm{H}}{ }_{\text {it }}$ & $\begin{array}{l}0.6163 \\
(0.2056)^{\mathrm{a}}\end{array}$ & $\begin{array}{l}0.4842 \\
(0.1988)^{\mathrm{a}}\end{array}$ & $\begin{array}{l}0.3608 \\
(0.1373)^{\mathrm{a}}\end{array}$ & $\begin{array}{l}0.4304 \\
(0.1424)^{\mathrm{a}}\end{array}$ \\
\hline $\mathrm{Q}_{\text {it }}$ & $\begin{array}{l}0.00026 \\
(0.00034)\end{array}$ & & & $\begin{array}{l}0.00023 \\
(0.00028)\end{array}$ \\
\hline $\mathrm{LEV}_{\text {it }}$ & & $\begin{array}{l}-0.00051 \\
(0.00096)\end{array}$ & & $\begin{array}{l}-0.0010 \\
(0.0010)\end{array}$ \\
\hline $\operatorname{Rum}_{\text {it }}$ & & & $\begin{array}{l}-0.00096 \\
(0.00051)^{\mathrm{c}}\end{array}$ & $\begin{array}{l}-0.0011 \\
(0.00054)^{b}\end{array}$ \\
\hline $\mathrm{m} 1$ & 0.01 & 0.02 & 0.02 & 0.02 \\
\hline $\mathrm{m} 2$ & 0.13 & 0.12 & 0.47 & 0.65 \\
\hline Sargan & 0.31 & 0.44 & 0.58 & 0.21 \\
\hline
\end{tabular}

Notes:

1. Time dummies are included in all specifications. Industry dummies (in the levels equations) are insignificant and thus excluded.

2. Predicted probabilities taken from a recursively-estimated takeover likelihood model.

3. All equations estimated with one-step GMM system estimator. All independent variables except for age (which is treated as exogenous) are instrumented. Instruments for equations in first-differences are as in Table 4.5, with additional regressors instrumented with twiceand further-lags. Instruments for equations in levels are as in Table 4.5, with the addition of $\Delta \mathrm{Rum}_{\mathrm{it}-1}$ in Columns 3 and 4 . Sargan test rejects $\Delta(D / Y)_{\mathrm{it}-1}, \Delta \mathrm{Q}_{\mathrm{it}-1}$ and $\Delta \mathrm{LEV}_{\mathrm{it}-1}$.

4. In parentheses are asymptotic standard errors robust to general cross-section and timeseries heteroskedasticity. The superscript ' $a$ ' indicates that the coefficient is significantly different from zero at the 0.01 level, 'b' at the 0.05 level and 'c' at the 0.10 level.

5. $\mathrm{m} 1$ and $\mathrm{m} 2$ are test statistics, distributed standard normal, for first- and second-order serial correlation in the first-differenced residuals. Sargan statistic is that for the corresponding two-step GMM estimator, distributed chi-squared. P-values are reported. 


\section{References}

Agrawal, A \& R A Walkling. 1994. Executive Careers and Compensation Surrounding Takeover Bids. Journal of Finance 49(3): 985-1014.

Aharony, J \& I Swary. 1980. Quarterly Dividend and Earnings Announcements and Stockholders' Returns: An Empirical Analysis. Journal of Finance 35(1): 1-12.

Arellano, M \& S Bond. 1991. Some Tests of Specification for Panel Data: Monte Carlo Evidence and an Application to Employment Equations. Review of Economic Studies 58(2): 277-297.

Arellano, M \& S Bond. 1998. Dynamic Panel Data Estimation using DPD98 for GAUSS. Mimeo, Institute for Fiscal Studies, London.

Arellano, M \& O Bover. 1995. Another Look at the Instrumental Variable Estimation of ErrorComponents Models. Journal of Econometrics 68(1): 29-51.

Asquith, P \& D W Mullins, Jr. 1983. The Impact of Initiating Dividend Payments on Shareholders' Wealth. Journal of Business 56(1): 77-96.

Bean, C R. 1981. An Econometric Model of Manufacturing Investment in the UK. Economic Journal 91(361): 106-121.

Bebchuk, L A \& L A Stole. 1993. Do Short-Term Objectives Lead to Under- or Overinvestment in LongTerm Projects? Journal of Finance 48(2): 719-729.

Benartzi, S, Michaely, R \& R H Thaler. 1997. Do Changes in Dividends Signal the Future or the Past? Journal of Finance 52(3): 1007-1034.

Blundell, R \& S Bond. 1997. GMM Estimation with Persistent Panel Data: An Application to Production Functions. Mimeo, IFS, London.

Blundell, R \& S Bond. 1998. Initial Conditions and Moment Restrictions in Dynamic Panel Data Models. Journal of Econometrics 87(1): 115-143.

Blundell, R, Bond, S, Devereux, M \& F Schiantarelli. 1992. Investment and Tobin's Q. Journal of Econometrics 51(1-2): 233-257.

Blundell, R, Bond, S \& C Meghir. 1992. Econometric Models of Company Investment. In Matyas, L \& P Sevestre, eds. The Econometrics of Panel Data: Handbook of Theory and Applications. Dordrecht: Kluwer Academic. Pages 388-413.

Bond, S R, Chennells, L \& M P Devereux. 1996. Taxes and Company Dividends: A Microeconometric Investigation Exploiting Cross-Section Variation in Taxes. Economic Journal 106(435): 320-333.

Bond, S, Elston, J, Mairesse, J \& B Mulkay. 1997. Financial Factors and Investment in Belgium, France, Germany and the UK: A Comparison Using Company Panel Data. NBER Working Paper No. 5900. 
Bond, S, Meghir, C \& F Windmeijer. 1998. Productivity, Investment and the Threat of Takeover. Mimeo, IFS, London.

Brook, Y, Hendershott, R \& D Lee. 1998. The Gains from Takeover Deregulation: Evidence from the End of Interstate Banking Restrictions. Journal of Finance 53(5), forthcoming.

Cameron, A C \& F A G Windmeijer. 1997. An R-squared Measure of Goodness of Fit for Some Common Nonlinear Regression Models. Journal of Econometrics 77(1): 329-342.

Campbell, J Y \& R J Shiller. 1988. Stock Prices, Earnings, and Expected Dividends. Journal of Finance 43(3): 661-676.

Comment, R \& G W Schwert. 1995. Poison or Placebo? Evidence on the Deterrent and Wealth Effects of Modern Antitakeover Measures. Journal of Financial Economics. 39(1): 3-44.

Comment, R \& G W Schwert. 1997. Hostility in Takeovers: In the Eyes of the Beholder? Mimeo, University of Rochester.

Dann, L Y \& H DeAngelo. 1988. Corporate Financial Policy and Corporate Control: A Study of Defensive Adjustments in Asset and Ownership Structure. Journal of Financial Economics 20(1/2): 87127.

DeAngelo, H, DeAngelo, L \& D J Skinner. 1992. Dividends and Losses. Journal of Finance 47(5): 18371863.

DeAngelo, H, DeAngelo, L \& D J Skinner. 1996. Reversal of Fortune: Dividend Signaling and the Disappearance of Sustained Earnings Growth. Journal of Financial Economics 40(3): 341-371.

Denis, D J, Denis, D K \& A Sarin. 1997a. Ownership Structure and Top Executive Turnover. Journal of Financial Economics 45(2): 193-221.

Denis, D J, Denis, D K \& A Sarin. 1997b. Agency Problems, Equity Ownership, and Corporate Diversification. Journal of Finance 52(1): 135-160.

Denis, D J \& J M Serrano. 1996. Active Investors and Management Turnover Following Unsuccessful Control Contests. Journal of Financial Economics 40(2): 239-266.

Dickerson, A P, Gibson, H D \& E Tsakalotos. 1998. Takeover Risk and the Market for Corporate Control: The Experience of British Firms in the 1970s and 1980s. University of Kent at Canterbury, Department of Economics Discussion Paper 98/3.

Edlin, A S \& J E Stiglitz. 1995. Discouraging Rivals: Managerial Rent Seeking and Economic Insufficiencies. American Economic Review 85(5): 1301-1312.

Fama, E F \& H Babiak. 1968. Dividend Policy: An Empirical Analysis. Journal of the American Statistical Association 63: 1132-1161.

Feldstein, M S. 1970. Corporate Taxation and Dividend Behaviour. Review of Economic Studies 37(1): 57-72. 
Franks, J \& C Mayer. 1990. Takeovers, Capital Markets and Corporate Control: A Study of France, Germany and the UK. Economic Policy 10: 189-231.

Franks, J \& C Mayer. 1996. Hostile Takeovers and the Correction of Managerial Failure. Journal of Financial Economics 40(1): 163-181.

Gilchrist, S \& C P Himmelberg. 1995. Evidence on the Role of Cash Flow for Investment. Journal of Monetary Economics 36(3): 541-572.

Greene, W H. 1997. Econometric Analysis. London: Prentice-Hall. Third Edition.

Greenwood, J, Hercowitz, Z \& P Krusell. 1997. Long-Run Implications of Investment-Specific Technological Change. American Economic Review 87(3): 342-362.

Higson, C \& J Elliott. 1998. Post-takeover Returns: The UK Evidence. Journal of Empirical Finance 5(1): $27-46$

Hulten, C R. 1992. Growth Accounting When Technical Change Is Embodied in Capital. American Economic Review 82(4): 964-980.

Jensen, M C. 1986. Agency Costs of Free Cash Flow, Corporate Finance, and Takeovers. American Economic Review 76(2): 323-329.

John, K \& J Williams. 1985. Dividends, Dilution, and Taxes: A Signalling Equilibrium. Journal of Finance 40(4): 1053-70.

Kaplan, S N, Mitchell, M L \& K H Wruck. 1996. A Clinical Exploration of Value Creation and Destruction in Acquisitions: Organizational Design, Incentives, and Internal Capital Markets. Forthcoming in Kaplan, S N, ed. Mergers and Productivity. NBER.

Layard, R. 1997. What Labour Can Do. London: Warner Books.

Lichtenberg, F R. 1992. Corporate Takeovers and Productivity. Cambridge, MA: MIT Press.

Lintner, J. 1956. Distribution of Incomes of Corporations among Dividends, Retained Earnings, and Taxes. American Economic Review 46: 97-113.

Loughran, T \& A M Vijh. 1997. Do Long-term Shareholders Benefit from Corporate Acquisitions? Journal of Finance 52(5): 1765-1790.

Manne, H G. 1965. Mergers and the Market for Corporate Control. Journal of Political Economy 73: 110120.

Marris, R. 1963. A Model of the 'Managerial' Enterprise. Quarterly Journal of Economics 77: 185-209.

Martin, K J \& J J McConnell. 1991. Corporate Performance, Corporate Takeovers, and Management Turnover. Journal of Finance 46(2): 671-687.

McGuckin, R H \& S V Nguyen. 1995. On Productivity and Plant Ownership Change: New Evidence from the Longitudinal Research Database. RAND Journal of Economics 26(2): 257-276. 
Mikkelson, W H \& M M Partch. 1997. The Decline of Takeovers and Disciplinary Managerial Turnover. Journal of Financial Economics 44(2): 205-228.

Milgrom, P \& J Roberts. 1992. Economics, Organization and Management. Englewood Cliffs, NJ: Prentice Hall.

Morck, R, Shleifer, A \& R W Vishny. 1988. Characteristics of Targets of Hostile and Friendly Takeovers. In Auerbach, A J, ed. Corporate Takeovers: Causes and Consequences. University of Chicago Press. Pages 101-129.

Morck, R, Shleifer, A \& R W Vishny. 1989. Alternative Mechanisms for Corporate Control. American Economic Review 79(4): 842-852.

Myers, S C. 1998. Outside Equity Financing. NBER Working Paper No. 6561.

Newey, W K. 1984. A Method of Moments Interpretation of Sequential Estimators. Economics Letters 14: 201-206.

Nickell, S J. 1995. The Performance of Companies. Oxford: Blackwell.

Nickell, S J. 1996. Competition and Corporate Performance. Journal of Political Economy 104(4): 724746.

Nickell, S \& D Nicolitsas. 1996. Does Innovation Encourage Investment in Fixed Capital? London School of Economics, Centre for Economic Performance Discussion Paper No. 309.

Nickell, S, Wadhwani, S \& M Wall. 1992. Productivity Growth in U.K. Companies, 1975-1986. European Economic Review 36(5): 1055-1085.

Nuttall, R. 1999a. Takeover Likelihood Models for UK Quoted Companies. Nuffield College, Oxford, Discussion Paper.

Nuttall, R. 1999b. Essays on Contracts and Takeovers. Unpublished doctoral thesis, Oxford University.

Pagan, A. 1984. Econometric Issues in the Analysis of Regressions with Generated Regressors. International Economic Review 25(1): 221-247.

Palepu, K G. 1986. Predicting Takeover Targets: A Methodological and Empirical Analysis. Journal of Accounting and Economics 8(1): 3-35.

Pesaran, M H \& A Timmermann. 1995. Predictability of Stock Returns: Robustness and Economic Significance. Journal of Finance 50(4): 1201-1228.

Poterba, J M. 1987. Tax Policy and Corporate Saving. Brookings Papers on Economic Activity 2: 455503.

Powell, R G. 1997. Modelling Takeover Likelihood. Journal of Business Finance \& Accounting 24(7/8): 1009-1031. 
Rau, P R \& T Vermaelen. 1998. Glamour, Value and the Post-Acquisition Performance of Acquiring Firms. Journal of Financial Economics 49(2): 223-253

Ravenscraft, D J \& F M Scherer. 1987. Mergers, Sell-offs, and Economic Efficiency. Washington, DC: Brookings.

Scharfstein, D. 1988. The Disciplinary Role of Takeovers. Review of Economic Studies 55(2): 185-199.

Schmidt, K M. 1997. Managerial Incentives and Product Market Competition. Review of Economic Studies 64(2): 191-213.

Schranz, M S. 1993. Takeovers Improve Firm Performance: Evidence from the Banking Industry. Journal of Political Economy 101(2): 299-326.

Schumann, L. 1988. State Regulation of Takeovers and Shareholder Wealth: The Case of New York's 1985 Takeover Statutes. RAND Journal of Economics 19(4): 557-567.

Shleifer, A \& L H Summers. 1988. Breach of Trust in Hostile Takeovers. In Auerbach, A J, ed. Corporate Takeovers: Causes and Consequences. University of Chicago Press. Pages 33-56.

Shleifer, A \& R W Vishny. 1989. Management Entrenchment: The Case of Manager-Specific Investments. Journal of Financial Economics 25(1): 123-139.

Shleifer A \& R W Vishny. 1997. A Survey of Corporate Governance. Journal of Finance 52(2): 737-783.

Stein, J C. 1988. Takeover Threats and Managerial Myopia. Journal of Political Economy 96(1): 61-80.

Stein, J C. 1989. Efficient Capital Markets, Inefficient Firms: A Model of Myopic Corporate Behavior. Quarterly Journal of Economics 104(4): 655-669.

Temple, J. 1998. Equipment Investment and the Solow Model. Oxford Economic Papers 50(1): 39-62.

Zwiebel, J. 1996. Dynamic Capital Structure under Managerial Entrenchment. American Economic Review 86(5): 1197-1215. 